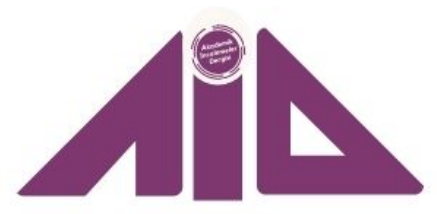

\title{
Tanrı ve Mesih Adına Siyaset: Donald Trump Yönetimi Döneminde Evanjelizm ABD Dıș Politikası Üzerindeki Artan Etkisi
}

\author{
Politics in the name of God and Jesus: Evangelicalism's Rising \\ Influence on U.S.Foreign Policy During DonaldTrump's \\ Presidency Period \\ Onur Mert ÇELIK \\ Yüksek Lisans Yıldız Teknik Üniversitesi, \\ omertozcelikk@gmail.com \\ https://orcid.org/0000-0002-0708-7941 \\ Mehmet Akif OKUR \\ Prof.Dr. Yıldız Teknik Üniversitesi, \\ İktisadi ve İdari Bilimler Fakültesi, Siyaset Bilimi ve Uluslararası İlișkiler Bölümü \\ mehmetakifo@yahoo.com \\ https://orcid.org/0000-0001-5095-6113
}

\section{Araștırma \& Yayın Etiği \\ Bu makale en az iki hakem tarafindan incelenmiș, iThenticate yazılımı ile taranmış, araștırma yayın ve etiğine aykırıık tespit edilmemiștir.}

\section{BY-NC 4.0}

Bu makale Creative Commons Attribution-NonCommercial License altında lisanslanmıștır.

This paper is licensed under a Creative Commons Attribution-NonCommercial License

\section{Research \& Publication Ethics}

This article was reviewed by at least two referees, a similarity report was obtained using iThenticate, and compliance with research/publication ethics was confirmed.

\section{Atıf/Citation}

Çelik, M. Onur - Okur, M. Akif. "Tanrı ve Mesih Adına Siyaset: Donald Trump Yönetimi Döneminde Evanjelizm ABD Dış Politikası Üzerindeki Artan Etkisi". Akademik Incelemeler Dergisi 16 / 2 (Ekim 2021): 1-25. https://doi.org/10.17550/akademikincelemeler.871002

Makale Türü/Article Type: Araştırma Makalesi/Research Article

Geliş Tarihi/Date Received: 30.01.2021

Kabul Tarihi/Date Accepted: 20.08.2021

Yayın Tarihi/Date Published: 15.10.2021

ISSN: $\quad 1306-7885$

E-ISSN: $2602-3016$ 


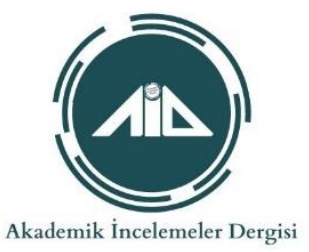

\title{
Trump Yönetimi Döneminde ABD’nin İsrail ve İran Politikası: Köktenci
}

\section{Evanjeliklerin Etkisi}

\section{Öz}

Amerikan tarihi ve demografik yapısından kaynağını alan nedenlerden ötürü evanjelizm, Amerikan toplumunun önemli bir çoğunluğunun dünya görüşünü şekillendirmiş ve toplumun en alt kademesinden devletin en üst düzey yetkililerine kadar etkisini göstermiştir. Ancak evanjelik Hıristiyanlar dini açıdan ve politik olarak yekpare olmamışlardır. Amerika Birleşik Devletleri'nde hemen her Protestan mezhebinde evanjelikler bulunabilmekle beraber birçok farklı inanç, çeşitli alt kültürler ve birbirine zıt görüşler taşıyan evanjelizmler de söz konusu olmuştur. 1970'li yılların başından itibaren ise yeni muhafazakâr sağ olarak da adlandırılan ve gerek kiliselerde gerekse tesis ettikleri çeşitli sivil toplum organizasyonları aracılığıyla kamuoyunda görünürlükleri artan ve $\mathrm{ABD}$ siyasetinde etkili bir güç haline gelen köktenci görüşlere sahip evanjelik gruplar öne çıkmaya başlamışıtır. Bu çalışma, bu köktenci evanjelik grupların Donald Trump yönetimi döneminde ABD'nin Ortadoğu'ya yönelik izlediği politikalara olan etkisini incelemektedir. Bu kapsamda evanjeliklerin iç ve dış politikada bir baskı grubu olarak çıkar algılarını açıklama, özel olarak ilgilendiği dış politika alanlarını tanımlama ve Evanjelik hareketin Donald Trump ve yönetimindeki diğer isimlerle etkileşimleri ve bağlantılarını gözlemlemeye çalışmaktadır.

Anahtar Kelimeler: Siyaset Bilimi ve Uluslararası İlişkiler, Amerikan Dış Politikası, Trump’ın Başkanlık Dönemi, Evanjelizm, Aşamalı Kadercilik

\section{US Policy Toward Israel And Iran During Trump Administration: The Influence of Fundamentalist Evangelicals}

\begin{abstract}
Evangelicalism, due to the reasons stemming from the American history and demographic structure, has shaped the worldview of the majority of American society and has shown its influence from the lowest level of society to the highest officials of the government. However, evangelical Christians are not religiously and politically monolithic. Although evangelicals can be found in almost every Protestant sect in the United States, there have been many different beliefs, various subcultures, and evangelicalism with opposing views. Since the early 1970s, evangelical groups with fundamentalist views, which are also called the neoconservative right, have increased their visibility in public opinion both within churches and through the various non-governmental organisations which they have established and have become an influential force in US politics. This study examines the effects of these fundamentalist evangelical groups on the US policies towards the Middle East during the Donald Trump administration period. In this context, it tries to explain the interests perceptions of evangelicals as a pressure group in domestic and foreign policy, to define the foreign policy areas in which they are particularly interested, and to observe the interactions and connections of the evangelical movement with Donald Trump and other actors under his administration.
\end{abstract}

Keywords: Political Science and International Relations, U.S. Foreign Policy, Trump's Presidency Period, Evangelicalism, Dispensationalism 


\section{Giriş}

Amerikan halkı için din unsuru, tarih sahnesine çıktıkları ilk zamanlardan itibaren diğer uluslarla olan ilişkilerinde belirleyici faktörlerden biri olmuştur. Bugünkü Kuzey Amerika topraklarında İngiliz kolonilerinin hüküm sürdüğü dönemde Protestanlık bir reform sürecinden geçmiş ve Amerikan ulusu "kilise ruhuna sahip bir millet" niteliği kazanarak Amerika Birleşik Devletleri (ABD) bizzat "dini bir fikir" olarak kurulmuştur (Chersterton, $2016,12)$. Chersterton'a göre $(2006,15)$ bu durum, Amerika'yı en pragmatik olması gereken zamanlarda bile dini açıdan idealist bir ülke haline büründürmüştür. Amerikan dış politikasında çeşitli dönemlerde gözlenen izolasyonculuk, realizm ve idealizm gibi siyasetlerin hepsinde çeşitli dini alt akımlar vuku bulmuştur.

1730'ların ve 1740'ların Büyük Uyanışı (Great Awaking), din olgusunun Amerikan siyasi düşüncesiyle iç içe geçmesinde önemli pay sahibi olmuştur. Birinci Anayasa Değisşikliği ile birlikte Amerika Birleşik Devletleri'nin “Tanrı'nın seçtiği ulus” olduğu ve Amerikan anayasasının da ilhamını tanrısal bir iradeden aldığı fikri kök salmıștır (Preston, 2012, 87). 19. Yüzyılın başlarında meydana gelen bu dini uyanış hareketleri, Amerikan toplumunu hükümetin tepesinden toplumun en alt basamağına kadar giderek EvanjelikProtestan bir ülke haline getirmiş ve nihayetinde evanjelizm, Randall Balmer'ın "Amerika'nın halk dini" dediği unsur haline gelmiștir (Balmer, 2006, 68-74).

Bununla birlikte Birinci ve İkinci Büyük Uyanışları takip eden ihya (revival) döneminden sonra Protestanlık içinde bir dizi tartışma meydana çıkmıştır. Balmer'e göre $(2006,19-$ 45) temel çatışma, Hristiyanlığa yeni düşünce biçimleri getirmeye çalışan ve İncil dilinin mecazi olarak yorumlanabileceğine inanan teolojik modernizm gibi ilerlemeci (progressive) yorumlar ile buna karşı çıkan köktenci Hristiyanlar arasında olmuş ve bu köktenci gruplar kendilerini evanjelik olarak tanımakla beraber bu yeni yorum şemasını reddetmiş ve kendilerini bu yeni evanjelik dalgadan ayırmışlardır. Dolayısıyla bu bölünme, İncil'i köktenci bir yorum ile okuyup anlayan ve bu yüzden modernizmi reddeden muhafazakâr bir dini grup olarak Amerikan evanjeliklerinin gelişiminde önemli bir aşama olmuştur. Artık evanjelik kimliğin temel bir parçası haline gelen köktenci inançlar, siyasete dair taşıdıkları temel endișe noktalarıyla da uyum göstermiş ve evanjeliklerin daha sonra politik meselelere olan yaklaşımlarına tesir edecek bir nitelik teşkil etmiştir.

$\mathrm{Bu}$ iki farklı yorum teolojik anlamda da bin yll öncecilik (pre-millennialism) ve bin yıl sonracılık (post-millennialism) olmak üzere iki farklı dini düşünce okulu tarafından temsil edilmiştir. Bin yıl sonracılık insanlığa dair iyimser bir görüşü benimsemekte ve Mesih'in kilise aracılığıyla dünyayı her geçen gün iyileştirdiğine inanarak İncil'de kehanet edilen Altın Çağ'ı bugünün dünyasında mevcut, halihazırda gelişen bir gerçeklik olarak kabul etmektedir (Leonhard, 2010, 74).

Bin yıl önceciler ise kötülüğün hâlâ canlı ve yükseliște olduğuna, büyük sıkıntı döneminin gelmesiyle birlikte bu durumun doruğa ulaşacağına inanmaktadır.

Bireysel olarak inananlar ve kiliseler dünyaya iyilik getirmek için çalışabilirler ancak bu sadece geçici bir çaba olacak, nihayetinde insanlık ve Kilise, şeytanın dünyasını günahtan arındırmada başarısız olacaktır. Hristiyanlar, ülkeler arasında barışı teşvik etmek için çabalayabilir ve savaşları protesto edebilirler ancak yalnızca "Barış Prensi" olan İsa, "insanların kılıçları saban demirlerine, mızrakları budama kancalarına dönüştürdüğü” bir krallık kurabilecektir. Dolayısıyla Leonhard'ın ifadesiyle $(2010,74)$ Mesih'in döndüğü dünya nihayetinde bir kargaşa ortamı olacaktır. 
1976 Başkanlık seçimleri, Amerikan diş politikasının ve din unsurunun artık birbiriyle esaslı bir bütün haline geldiği önemli bir değişikliğin habercisi olmuştur. Amerikalılar bir Baptist Pazar Okulu öğretmeni ve bin yıl sonracı görüşlere sahip (Carter, 2006, 153) Jimmy Carter'ı başkan seçmişlerdir. Carter, göreve başladıktan hemen sonra, ABD dış politikasını kendi evanjelik fikirleriyle uyumlu hale getirmiştir. Evanjelizmde çok önemli bir yer teşkil eden "yeniden doğuş" inancını benimseyen Carter, ABD'nin değişmeyen ahlaki temellere dayanan bir dış politika izlemesi gerektiğini savunmuştur (Balmer, 2006, 159).

Carter'ın Amerika Birleşik Devletleri Başkanlığı'na seçilmesi aynı zamanda kendisi ile benzer inancı taşıyor gibi görünen köktenci evanjelik çevrelerde de büyük umutlar doğurmuştur. Ancak ABD Başkanlığı'nı yürüttüğü dört yılın sonunda Carter, bu grupların beklentilerini karşılayamamış ve evanjelizmin Amerikan siyaseti ve dış politikasına olan etkisi bu noktadan sonra farklı bir seyir izlemiştir. Carter hükümetin gücünü bu evanjelik aktivistlerin dilediği ve onların algıladığı şekilde bir ahlak anlayışını yasal hale getirmek için kullanmak istememiştir (Isserman - Kazin, 2011, 305). Bu durumun nedeni Carter'ın evanjelizmi yorumlayıșı bin yıl sonracı ve ilerlemeci bir mantığa dayanırken köktenci evanjeliklerin İncil'i bin yıl önceci aşamalı kadercilik (dispensationalism) doktrinine göre değerlendirmesi olmuştur. Dolayısıyla bu köktenci evanjeliklerin Carter'dan istediklerini alamaması, onları ülkenin Yahudi-Hristiyan (Judeo-Christian) bir değerler sistemine dayandığına inandıkları kimliklerini yeniden tesis etmek ve bu değerleri yaymak için Amerikan askeri gücünü eski konumuna getirmeyi vadeden başka adaylar aramaya sevk etmiştir. Sonuç olarak evanjelikler, 1980 Cumhurbaşkanlığı seçimleriyle birlikte bir Hollywood aktörü ve eşinden boşanmış olan ve çok dindar bir geçmişi bulunmayan Ronald Reagan'ı Pazar Okulu öğretmeni Jimmy Carter'a karşı desteklemiştir. (Marsden, 2006).

Sonuç olarak Carter yönetimi sırasında görünürlük kazanıp etkilerini arttıran ve Reagan'ın Başkanlığı ile birlikte tamamıyla politik olarak sağa sürüklenerek Cumhuriyetçi partiyle eklemlenen bu yeni muhafazakâr evanjelik gruplar, evanjelizm ile ilgili klasik görüşleri değişime uğratmış ve günümüzde de Demokrat Parti'ye egemen olan bin yll sonracı, ilerlemeci ve liberal eğilimlere yönelik tepkilerin bayraktarlığını yapmıștır. Bu grupların etkilediği beyaz Evanjelik seçmen, 2016 seçimlerinde yüzde 81 gibi yüksek bir çoğunlukla Donald Trump'a oy vermiştir. Esasında Donald Trump, evanjelik ahlak anlayışı bakımından hiç de uygun bir aday gibi gözükmese de bu seçmen grubu, Trump için önceki dört Cumhuriyetçi adaya kıyasla daha yüksek bir oranda oy kullanmıştır (Martinez Smith, 15 Şubat 2020). Trump'ın dış politikaya yaklaşımı ve bu politikaların oluşumunda hükümet aygıtlarını kullanış tarzı kendisine özgü olsa da, onun iç ve dış meselelere olan yaklaşımı, bu köktenci Evanjelik anlayışla aynı dini ve ahlaki hassasiyete dayanmamakla beraber benzer kaygılar taşımıştır.

$\mathrm{Bu}$ çalışma, evanjelizm özelinde dini bir arka plana dayanan dünya görüşlerinin bir ülkenin dış politikasında belirgin bir unsur olarak öne çıkmasının hangi durum ve şartlar altında mümkün olabileceğini göstermeyi amaçlamaktadır. Yine bu çalışma, evanjelik gruplarla Amerikan yönetimi arasındaki ilişkilerin, ABD'nin izlemiş olduğu dış politikalarda önemli bir etkiye sahip olduğu hipotezi üzerine inşa edilmiştir. Bu kapsamda evanjelizm inancı ve evanjelikler, çeşitli yöntemler aracılığıyla ABD dış politikasını etkileyen unsurlar olarak sunulmaktadır. Bu çalışmada ortaya konulan analizler, evanjelik grupların savunup destekledikleri çeşitli dış politika girişimlerine ve gerçekleştirmiş oldukları lobi çalışmalarına odaklanmaktadır. Bu çerçeve içinde bu çalışma, bin yıl önceci aşamalı kaderci inançlara sahip köktenci evanjelik anlayıșı benimseyenlerin Donald 
Trump'ın izlediği dıș politikaya etkilerini incelemektedir. Grossman ve Matthews 2009 yılında yayınlamış oldukları eserinde Amerikalıların yüzde 40'ından fazlasının kendilerini bir tür "Evanjelik" olarak tanımladıklarını savunmuştur (Grossman Matthews, 2009, 120-136). Bu oran her ne kadar tartışmalı gibi gözükse de ve hatta "Evanjelikler" nüfusun çok daha az bir kısmını temsil etse bile grubun Amerikan yönetimleri üzerindeki etkilerini -onların amaçlarını, inançlarını, görüşlerini ve politikalarını anlamak için- incelemeye değer kılmaktadır.

\section{Kavramsal Çerçeve}

Tarihçilere göre evanjelikleri dört temel unsur tanımlamaktadır: İncil'in dini konularda en yüksek otorite olduğu anlamına gelen "Biblicizm", İsa'nın tüm insanoğlunun günahları için kendini kurban ederek çarmı ha gerilmesine odaklanan "Crucicentrism", evanjelizmin "yeniden doğuş (born again)" boyutunu kapsayan "Conversionism" ve "Aktivizm" (Hankins, 2008, 1). Evanjelik Protestanlığın bu son unsuru siyasete bağlanabilir. Aktivizm, evanjelik olmanın merkezi bir parçasıdır. Hankins'e göre bu aktivizm $(2008,2)$, ahlaki ve politik konularda aktif olmanın yanında insanları bilinçlendirmek üzere vaaz verme ve misyonerlik çalışmaları gibi birçok biçim alabilir. Tüm bu unsurlar mevcutsa, bir kişi evanjelik olarak tanımlanabilir. Ancak Evanjelik Hıristiyanlar dini açıdan ve politik olarak yekpare değillerdir. Amerika Birleşik Devletleri'ndeki hemen her Protestan mezhebinde evanjelikler bulunabilir (Berggren - Rae, 2006, 6). Birçok belirgin kişilik, çeşitli alt kültürler, birçok farklı evanjelik ve evanjelizm vardır. Dolayısıyla tarihsel süreç içerisinde birçok farklı evanjelizm ve yine birçok farklı dinamik çerçevesinde gelişen ve hatta birbirinin tam zıttı eğilimlere sahip olan çeşitli Evanjelik hareketler meydana çıkmıştır. Ancak evanjeliklerin ABD dış politikasına olan etkilerini kavramsallaştırmak gerektiğinde, evanjeliklerin İncil kehanetlerine bağlı olarak insanlığın nihai kaderini veya dünya tarihini sonuçlandıracağına inandıkları olayları içeren eskatolojik boyuta ve İsrail'e olan desteklerine bakmak gerekmektedir.

\subsection{Eskatolojik Boyut}

Hıristiyan eskatolojisi, Batı felsefesi ve fikriyatının gelişiminde çok güçlü bir etkiye sahip olmuştur. Dördüncü yüzyıldan itibaren Roma İmparatorluğu'nun Hristiyanlaşması ile birlikte Hristiyanlığın İncil'deki kehanetlere ve ahir zamanlara dair ortaya koyduğu yorumlar, ülkelerin yönetim felsefelerini etkilemiş ve güncel sorun alanlarının belirlenmesi ve bu sorunların çözümünde bir rehber işlevi görmüștür. Roma'nın ardından Batı dünyasında ortaya çıkan ve Hıristiyanlığın etkisi altında kalan birçok devlet, İncil kehanetlerine dair yorumlarını ulusal ideolojilerine entegre etmeye çalışmışlardır. $\mathrm{Bu}$ kehanetçilik geleneği ile ABD kuruluş ideolojisinin karışımından doğan birtakım ilke ve prensipler, Amerikan dış politikasının işleyişine önemli ölçüde sirayet etmiştir (Leonhard, 2010, 91). Dolayısıyla Amerikan diş politikası, kilise geleneklerinden ve bu kehanetlerin yorumlanmasından geniş anlamda etkilenmiş ve bu yorumlar Amerikalıların dünyaya dair bakış açılarını belirlemiştir. Buna bağlı olarak ABD; iki temel ancak birbirine zıt yorumları barından dini düşünce okullarının çatıştığı farklı dış politika yaklaşımlarına sahip olmuş ve dış politikasını bu diyalektik etrafında şekillendirmiştir.

Hıristiyan eskatolojisindeki en temel tartışma konusu, Mesih'in Altın Çağ’a göre geri dönüşünün zamanlamasıyla ilgilidir. Bu kapsamda "bin yıl öncecilik" ve "bin yıl sonracılık" olmak üzere iki farklı düşünce okulu öne çıkmaktadır. Temelde binyıl öncecilik, Mesih'in gelecekte yeryüzüne tekrar geri dönüp dünyanın gidişatına müdahale edeceğini ve ardından bin yıl boyunca sürecek krallığını kurarak Altın Çağ’ı getireceğini öngörmektedir. Bu görüşten farklı olarak binyıl sonracılık, Mesih'in dünyaya geri 
dönüşünün Altın Çağ'dan sonra meydana geleceğini ve var olan kötü düzeni ortadan kaldırmak için bir geri dönüşü gerektirecek durum olmadığını çünkü zaten halihazırda Mesih'in Kilise aracılığıyla aktif olduğunu savunmaktadır (Leonhard, 2010, 60-61). Buna göre Altın Çağ'a kilisenin gayretleriyle varılacak ve Mesih'in gelişi, Tanrı'nın insanlığa dair nihai kararını vermesinden hemen önce insanlığı son bir kez denetlemek ve Tanrı'nın takdirine şahitlik etmek üzere Altın Çağ'dan sonra yaşanacaktır.

Sonuç olarak bin yıl sonracılık, doğası gereği iyimserdir ve yüce bir hedef olarak dünyayı herkesin mutluluğu için daha iyi bir yer haline getirmeye odaklanmakta ve bu amaç doğrultusunda en büyük itici gücün Tanrı olduğu konusunda ısrar etmektedir (Boettner, 1991, 192). Bin yıl sonracı görüș, dogma veya ortodoksiyi vurgulamamakta aksine başkalarına yardım ederek ve Mesih'in sevgisini göstererek Hristiyanlığı eylemde uygulamaya çalışmaktadır. Dolayısıyla bin yıl sonracılık, politik doğrucudur (Leonhard, 2010, 84).

Bin yıl öncecilik ise tam tersine kötümser bir inançtır ve diğer dinlerden hatta Hıristiyanlık içindeki diğer mezheplerden bile oldukça şüpheli olma eğilimindedir, ötekilerle iyi geçinemez (Boettner, 1991, 193). Bu doktrinsel diyalektiğin en önemli sonuçlarından biri, bin yıl önceciliği savunanların birçok kez bin yıl sonracı tasvirleri ödünç alarak kendi inançlarını maskelemeye çalışması olmuştur. George W. Bush, bin yıl önceci senaryoya inanmasına rağmen özgürlük, adalet, refah ve barışın hüküm sürdügü bir dünya için çabalamaktan söz etmiştir. Keza 2018'de ABD yönetiminin İsrail Büyükelçiliği'ni Tel Aviv'den Kudüs'e taşımasının ardından Trump yönetimine destek veren birçok evanjelik lider yine bu tür kavramlara başvurmuştur.

Böylelikle bin yıl öncecilik, Amerikan dış politikasında sıklıkla bin yıl sonracı kostümlerle kendini gizlemiştir (Leonhard, 2010, 84).

Bin yıl önceciliği savunan aşamalı kaderci Evanjelik görüşün siyasi ve teolojik temelleri, köktenciliğin Amerikan kurumlarını derinden şekillendiren bin yıl sonracı ve ilerlemeci (progressivist) anlayışa tepki olarak ortaya çıktığı 19. Yüzyılın sonlarında bulunabilir. Aşırı muhafazakâr bir karaktere sahip olan bu anlayıș, aşamalı kadercilik doktrininin serpilmesiyle varlık kazanmıştır. Aşamalı kaderciler, Tanrı'nın dünya tarihini, insanlığa ayrı ayrı yazgılar (dispensation) bahşettiği çağlara böldüğüne inanmışlardır. Hıristiyanlığın doğumundan sonraki dönem, tüm Hıristiyanların dünyanın sonuna hazırlanırken Evanjelikleşmeleri beklenen bir ek süre olarak görülmüştür. Bu inanca göre, ahir zamanların gelmesiyle birlikte dünya büyük bir kargaşa içine girecek ve bu devrin son 7 yılını kapsayan "büyük sıkıntı (tribulation)" döneminden önce hakiki inananlar cennete taşınacaktı (rapture). Ardından Mesih ikinci kez dünyaya gelip Kudüs'ü işgal etmiş olan Deccal güçlerine karşı vereceği savaş sonunda bin yll boyunca sürecek bir krallık kuracaktı (Marsden, 2006, 55-62). Bu bin yılın sonunda Tanrı, insanlığa dair nihai kararını (final judgment) verecek ve dünya son bulacaktı. Bu inanç biçimine bağlı olarak aşamalı kaderciler, seçilmiş bir halk olarak Yahudilerin Tanrı'nın dünyaya dair planında özel bir misyonu bulunduğuna inanmıştır (Leonard, 2010, 59). Aşamalı kaderciler, bilhassa ahir zamanlardaki rolü dikkate alındığında İsrail'in her koşulda desteklenmesini bir inanç ve itikad meselesi olarak görmüştür.

Aşamalı kaderciliğin İncil'e dayandırdığı kehanetlerle kurgulanmış bu inanç biçimi, Evanjelik hareket etrafında bir tüketici kültürünün 1970'lerde yaygınlaşmasıyla çok daha görünür hale gelmiştir. Bu akıma mensup çeşitli yazarların eserleri milyonlarca nüsha satmıştır. Televizyonlarda İncil'i vaaz eden papazlar kitle iletişim araçlarında görünüp tanınmaya başladıkça vaazlarında aşamalı kaderci itikadı teşvik etmişlerdir. Nükleer 
çağda, giderek yaklaşan ve dünyanın sonunu getireceğine inanılan Armageddon Savașı ile ilgili senaryolar büyük ilgi görmüştür. Konu üzerinde çalışan Paul Boyer (1994, 121-157), Soğuk Savaş yıllarının ABD'sinde nükleer savaş ve İncil kehanetleri arasında yakın bağlantılar kurulduğuna dikkat çekmektedir. Bu dönemde, siyaset ve teolojik alan birbirleriyle karıştıkça, dini inançlar ile politik hırslar arasındaki çizgiler de bulanıklaşmıștır.

Amerikan Protestanlı̆̆ı'nda ortaya çıkan bu yeni tür köktenci evanjelizmin büyüyüp kamuoyunda görünürlüğünün arttığı 1970’li yıllarla birlikte, daha liberal ve ana akım mezhepler zemin kaybetmiştir. Örneğin Amerika'nın en büyük Protestan mezhebi olan Güney Baptistleri tarihsel olarak cemaatin özerkliğini vurgularken ve resmi inanç beyanlarından kaçınırken, köktenciler 1979'da kilisenin kontrolünü ele geçirmişler ve İncil'in mecazi olarak yorumlanamayacağına ve Kutsal Kitap'ın yanılmazlığına vurgu yapmışlardır (Sandeen, 2008, 73-75).

2016 yılına gelindiğinde ise bin yıl önceci aşamalı kadercilik inancı, ABD Başkanı Donald Trump'ın gerek yakın danışmanları gerekse kabinesindeki isimler içinde yoğun ölçüde temsil edilmiş ve Trump yönetiminin izlediği politikalarda etkili olmuştur. Trump'ın her ne kadar bu tür dini inanç ve dünya görüşlerine bir aşinalığı bulunmasa da, düzen karşıtı ve popülist milliyetçi fikirleri, ABD’nin dünyadaki yerine ve izlemesi gerektiği diş politikaya dair algıları ve İsrail'e olan bakışı, evanjeliklerin aradıkları ideal Başkan adayı profiliyle uyumlu olmuştur.

\subsection{Bin Yıl Önceci Aşamalı Kadercilik ve İsrail’e Destek}

Bin yıl önceci aşamalı kaderci anlayışı benimseyen evanjelikler, İsrail'e olan desteklerini temel olarak iki gerekçeye dayandırmaktadırlar. Bunlardan ilkini Tanrı'nın Yaratılış (Genesis) Kitabı, 12:3'de "Yahudi halkını kutsayanları kutsayacağına, lanet edenleri de lanetleyeceğine” dair İbrahim'e verdiği söz teşkil etmektedir. Bu çerçevede Yahudi halkı Tanrı katında özel bir yere sahiptir ve Yahudi ülkesine destek, inanan bir Hristiyan için en temel gerekliliklerden biridir (Bird, 2013, 557). İkinci olarak ise ilk bölümde bahsedilen Vahiy Kitabı'ndaki (Book of Revelation) Ahir Zamanlar, Mesih'in ikinci geliși ve bin yıllık krallı̆̆ı süresince yaşanacak Altın Çağ ile ilgili kehanetlere vurgu yapmaktadırlar. Vahiy Kitabı'nın Mesih'in krallığının süresine (bin yıl) yaptığı atıf, Hıristiyanlar arasında gelecekteki Altın Çağ’ı tanımlamak için "Millennium” terimini ortaya çıkarmıştır. Bu nedenle "bin yıl önceci (Millenarian)" terimi, Mesih'in bin yıllık hükümdarlığına atıf yapan kehanetlerin gerçekleşeceğine inanan insanları tanımlamak için kullanılmaktadır (Leonard, 2010, 58).

16. ve 17. Yüzyıllarda İngiltere'deki Püritenler arasında popülerleşen ve 19. Yüzyılın başlarından itibaren ABD'de yayılarak dini bir okul haline gelen Așamalı Kaderciliğin İncil'deki kehanetlere getirdiği bu farklı yorum, günümüzdeki bin yıl önceci evanjelik hareketin görüşlerini büyük ölçüde şekillendirir hale gelmiştir. Așamalı Kaderciler, Eski Ahit'teki bu kehanetleri İsa Mesih'in beklenen dönüşüyle ilişkilendirmekte ve dünyanın sonunun bu kehanetlerin öngördügü bir olay örgüsü içinde geleceğini iddia etmektedirler (Noll, 1993, 617-627). Bu inanç biçimi; 20. Yüzyıldan itibaren Siyonist hareketin yükselişi, Filistin'de İngiliz mandasının tesisi sayesinde "vaat edilmiş topraklarda" Yahudi yerleşimlerinin sayısının artması, 1917 Balfour Deklarasyonu ve 1948'de İsrail Devleti'nin kurulması gibi gelişmelerle birlikte Mesih'in gelişinin yaklaştığı umudunu güçlendirmiş ve Evanjelikleri İncil'i doğru okuduklarına ve İncil'deki kehanetlerin aşamalı kaderci ahir zaman örgüsüne göre ortaya çıktığına ikna etmiştir (Lahr, 2007, 4). Tüm bu gelişmeler çerçevesinde aşamalı kadercilik, İsrail'in İncil kehanetleri içinde ve 
Tanrı nezdinde eşsiz bir öneme sahip olduğu fikrini Amerikan Evanjelizmine tanıtmıştır. ABD'deki Evanjelik Hıristiyanların çoğunluğu, bu ahir zaman kehanetleri sebebiyle İsrail hükümetinin en sadık destekçileri haline gelmiştir. (Hankins, 2008, 91).

Pew Araştırma Merkezi'nin Din ve Kamusal Yaşam üzerine 2013 yılında yaptığı bir ankete göre beyaz Evanjeliklerin \%82'si de dâhil olmak üzere Amerikalıların \%44'ü İsrail'in Yahudilere Tanrı tarafından bahședildiğine inanmaktadır (Lipka, 3 Ekim 2013). Böyle bir inanç modeli çerçevesinde dış politika, ilahi bir planın aracı haline gelmektedir. Dünyada ve bilhassa Ortadoğu'da yaşanan gelişmeler, İsa'nın ikinci gelişinin alametlerini gösterdiği ölçüde önem arz etmektedir. Bu çerçeveden bakıldığında, geçmişten bu yana Amerikan dış politikasında etkisini hissettirmiş güçlü aşamalı kaderci temalar bulunabilir. Son dönemde ise bu kıyamet ve ahir zaman inancına dayalı dünya görüşüne katılanlar, Trump'ın dini destekçileri, danışmanları olmuşlardır ve kabinesindeki en kritik makamlarda temsil edilmişlerdir. Donald Trump bu teolojik çerçeveye hâkim olmasa ve hatta inanmasa bile Evanjelik oyların \%81'ini alan ve kendisine en yakın iki karar verici konuma Evanjelikleri yerleștirmiş bir Başkan olarak politikalarındaki bu amil göz ardı edilmemesi gereken bir unsur olarak dikkat çekmektedir.

\section{Trump Yönetimi Döneminde İsrail-ABD İlişkileri}

2. Dünya Savaşı'ndan bu yana uluslararası sistemde en sağlam ve istikrarlı ikili ilişkilerden biri İsrail ile ABD arasında olmuştur. Bu özel ilişki biçimi hem Amerikan siyasi liderliği hem de Amerikan halkı tarafından uzun süre boyunca desteklenmiştir. İsrail'in kuruluşundan bu yana Amerikan liderleri, İsrail'i yoğun askeri ve ekonomik yardımlarla, İsrail'in bölge ülkeleriyle yaşadığı askeri çatışmalarda İsrail lehine müdahalelerde bulunarak, çatışmalar sonrası barış müzakereleri esnasında ve uluslararası alanda İsrail'in çlkarlarını gözeterek sürekli olarak desteklemişlerdir (Inbar, 2009). İsrail, Amerikan siyasetinde başlıca dış politika konularından biri olmuş, parti programları ve Başkanlık seçimlerinde düzenli olarak zikredilerek aynı zamanda bir iç politika meselesi haline gelmiştir (Cavari - Freedman 2017, 77). Başkanlar, görevleri esnasında rutin olarak konuşmalarında İsrail ile ilgili konuları ele almış ve ABD ile İsrail arasındaki özel ilişkinin yanı sıra İsrail'in güvenliğini de her zaman koruyup gözeteceğine tekrar tekrar söz vermişlerdir. Ayrıca Kongre Üyeleri, kampanyalarında İsrail'e sıklıkla atıfta bulunmuşlar, yasama eylemlerinde ve basın açıklamalarında da defaten İsrail'e desteklerini göstermişlerdir (Cavari - Nyer, 2014, 7-47; Garnham 1977, 23-45; Feuerwerger, 1979, 253-272).

Ancak son ylllarda İsrail'e yönelik bu yoğun destek değişim göstermektedir. Bir dizi çalışma, İsrail'e yönelik desteğin bir devlet duruşundan ziyade artık yalnızca Cumhuriyetçiler tarafından sahiplenildiğini ortaya koymaktadır (Oldmixon, vd., 2005, 407-426; Rosenson, vd., 2009, 73-91; Cavari - Nyer 2014). Seçim kampanyaları üzerine yapılan araştırmalar, İsrail-Filistin çatışmasının Başkanlık seçimlerinde ve kongre yarışlarında giderek daha fazla tartışıldığını ancak Cumhuriyetçi adaylar arasında çok daha baskın bir rol aldığını göstermektedir (Cavari - Freedman, 2017, 77). Buna göre Cumhuriyetçiler İsrail'e destek konusunda açık ve net bir görüş benimsemişken, Demokratlar İsrail'e desteği Filistin meselesiyle birlikte ele almaktadır. Öte yandan yakın zamana kadar her iki parti seçmeni de İsrail'e Filistinliler ve Araplardan daha fazla sempati duyarken günümüzde Cumhuriyetçilerin yaklaşık \%90'ı, Demokratların ise yalnızca \%50'si bu eğilimi benimsemektedir (Cavari - Freedman, 2019, 29-57).

2016 Kampanyası sırasında Donald Trump, ABD'nin önceliklerini değiștireceğine ve Amerikan yönetiminin İsrail hükümeti ile ilişkilerini yeniden güçlendireceğine söz 
vermiştir. Trump, Aralık 2016'da ABD'nin kararı veto etmemesiyle birlikte 14'e 0 oyla kabul edilen ve İsrail'in Filistin topraklarındaki yerleşim faaliyetlerinin uluslararası hukukun "açık bir ihlali" olduğunu belirten 2334 sayılı BM Güvenlik Konseyi Kararı'na sert tepki vermiştir (Guez, 28 Aralık 2016). Başkan Trump, göreve gelişinin üzerinden 1 ay geçmeden Netenyahu'yu Beyaz Saray'a davet etmiş ve ardından 3 ay sonra kendisi İsrail'i ziyaret etmiştir. Ziyareti esnasında Trump, Ağlama Duvarı'nda dua etmiş ve uluslararası toplumun çoğunluğu tarafından işgal altında bir bölge olarak görülen bu yeri ziyaret eden ilk Başkan olmuştur (Hirsch, 2005; Breger - Hammer, 2018).

Bunun yanı sıra Trump, İsrail'e güçlü desteğini göstermek için kampanya döneminde verdiği sözleri yerine getirmiştir. İsrail'in Golan Tepeleri üzerindeki egemenliğini tanımış, İran Nükleer Anlaşması'ndan çekilmiş, BM'de İsrail'e yönelik tek taraflı destek eylemleri gerçekleştirmiş ve ABD'nin İsrail'in güvenliği ve refahına olan bağlılığını defalarca vurgulamıştır. Trump yönetimi döneminde İsrail ile ABD arasındaki savunma, istihbarat ve diplomatik iş birliği her zamankinden daha geniş ve derin bir nitelik arz etmiştir. Trump'ın Başkanlığı döneminde Kongre, İsrail'e savunma yardımı için Obama dönemindeki bir mutabakat anlaşmasını kanun haline getirmiş ve böylece Amerika Birleşik Devletleri İsrail'e on yıl içinde 38 milyar dolar sağlamayı taahhüt etmiştir. Bu, İsrail'e savunma alanında yapılan en büyük transfer niteliğini taşımıştır. Trump, İsrail füze savunma sistemlerini desteklemek için bu yardımı 705 milyon dolarlık destekle tamamlamıştır (Wilner - Gross, 11 Eylül 2017). Ancak Trump'ın Evanjelikler nezdinde en çarpıcı hamleleri Kudüs'ü İsrail'in başkenti olarak tanıyarak ABD Büyükelçiliğini Kudüs'e taşıması ve İsrail'in Kudüs'ün neredeyse tamamında hâkimiyet sağlamasını öngören Barıș vizyonu tasarısı olmuştur. Çünkü Evanjelik inanç sistemine göre, İsrail'in kurulması ve El Aksa camisinin bulunduğu alan da dâhil olmak üzere Kudüs'ün tamamen ele geçirilmesi, ahir zaman kehanetlerinin yolunu açacağı düşünülmektedir.

\subsection{ABD’nin İsrail Büyükelçiliğini Kudüs'e Taşıma Kararı ve Barış Vizyonu Tasarısı}

1948 yılında İsrail Devleti'nin bağımsızlık ilanının ardından tetiklenen savaşın sonucunda İsrail, Kudüs'ün Batı kısmını işgal etmiş, Doğu Kudüs ise Ürdün yönetiminde kalmıştır (PASIA, 2007, 173). Ardından 1967 yılında gerçekleşen 6 Gün Savaşları'nın ardından İsrail, Doğu Kudüs'ü de işgal etmiş ve şehri bir bütün olarak İsrail'in ebedi başkenti olarak ilan etmiştir. Sonrasında uluslararası toplumun büyük çoğunluğunun yasadışı olarak kabul ettiği birçok yerleşim yeri inşa etmiştir. 6 Gün Savaşları sonucunda Birleşmiş Milletler, İsrail'in "son çatışmalarda işgal etmiş olduğu topraklardan" çekilmesi çağrısında bulunan 242 sayılı kararı almış ve ABD de bu karara iştirak etmiştir (Spiegel, 155).

ABD ayrıca İsrail'in Doğu Kudüs'ün ilhakına yönelik bir açıklama yayınlayarak, "bu girişimlerin Kudüs'ün statüsüne dair tutumlarında herhangi bir değişiklik" oluşturmadığını duyurmuştur (PASIA, 2007, 172). ABD’nin İsrail Büyükelçiliği'ni Kudüs'e taşımaya yönelik çağrılar, ilk olarak 1972 yılında, Kongre'de Cumhuriyetçi grubun lideri olan Gerald Ford'un Kudüs'ü "İsrail'in tarihi ve yasal başkenti" olarak tanımayı desteklediğini belirtmesiyle başlamıştır. Ancak Ford Başkan olduktan sonra "mevcut koşullar ve Ortadoğu'da adil ve kalıcı bir barış amacını" gerekçe göstererek bu önerinin şimdilik bir kenara bırakılması gerektiğini söylemiştir (Jewish Teleghraphic Agency, 29 Ağustos 1974). Ford'un bu tavrı, her kampanya döneminde Başkan adaylarının elçiliği taşıma sözü verdiği ancak Beyaz Saray'a gelişinin ardından bunu barış uğruna ertelediği bir dış politika geleneği haline gelmiștir.

1993 yılında İsrail ve Filistin Kurtuluş Örgütü (FKÖ) arasında Oslo Anlaşmaları imzalandıktan sonra, Kongre ABD’nin İsrail Büyükelçiliği meselesini tekrar gündeme 
getirmiştir. Mayıs 1995'te bir grup senatör elçiliğin Kudüs'e taşınması için bir yasa tasarısı önermiştir. Bill Clinton yönetimi, başkanlık kampanyası sırasında Büyükelçiliği Kudüs'e taşıma sözü vermesine rağmen bu tür bir yasanın barış sürecini ve ABD'nin arabulucu rolünü tehlikeye atacağını söylemiştir (PASIA, 2007, 298-299). Clinton yönetiminin bu tutumuna rağmen, tasarı Ekim 1995 'te Senato ve Temsilciler Meclisi'nden geçmiştir. Yasa tasarısında Başkanların ulusal çıkarlara uygun olduğuna karar vermeleri halinde altı ay süreyle kararı uygulamayabilmelerine izin veren bir hüküm yer almıştır (PASIA, 2007, 296-297). 2018 yılına kadar ABD yönetimleri bu hükme dayanarak büyükelçiliğin yerini değiştirme yönünde adım atmamışlardır. Clinton, Bush ve Obama, büyükelçiliğin taşınması halinde Arap dünyasında şiddetli bir tepki doğacağından çekinerek her altı ayda bir ilgili feragatnameleri imzalamışlardır.

2016 yılında ABD Başkanı seçilen Donald Trump, Kudüs'le ilgili hem Cumhuriyetçilerin hem Demokratların benimsediği, büyükelçiliğin Kudüs'e taşınmasını iki devletli çözüme ve müzakerelere bağlayan nispeten temkinli pozisyona kıyasla çok daha İsrail yanlısı bir üslup takınmıştır. Trump, Eylül 2016'da başkanlık kampanyası sırasında İsrail Başbakanı Benjamin Netanyahu ile görüşmüș ve "Kudüs'ün 3.000 yıldan fazla bir süredir Yahudi halkının ebedi başkenti olduğunu ve ABD'nin Trump yönetimi altında, Kongre'nin Kudüs'ü İsrail Devleti'nin bölünmemiş başkenti olarak tanımaya çağıran kararını" onaylayacağını bildirmiştir. Trump seçim kampanyasını yürütürken, göreve geldikten sonra büyükelçiliğin "oldukça hızlı bir şekilde" yerini değiştireceğini söylemiştir (Paker, 19 Kasım 2016).

İsrail Büyükelçiliği'nin Kudüs'e taşınması, vaktiyle başka Başkan adaylarının seçim kampanyalarında da gündeme gelmiş, bununla birlikte Başkan olduktan sonra hiçbiri bu adımı atamamıștır. Fakat Trump, İsrail'in Doğu Kudüs'teki hâkimiyetini tanımayan uluslararası toplumun tepkisine ve BM'nin bu tür bir eylemi yasadıșı olarak nitelendiren kararlarına rağmen 2018 yılında ülkesinin büyükelçiliğini Tel Aviv'den Kudüs'e taşıyan ilk dünya lideri olmuştur. 2020 yılında Wisconsin'deki bir mitingde yaptığı konuşmada Trump, bunu Evanjelikler için yaptığını söylemiştir (Jones, 18 Ağustos 2020).

Trump'ın kararı, uluslararası toplum tarafından güçlü bir muhalefetle karşılanmıştır. Birleşmiş Milletler Genel Kurulu (UNGA) ezici bir çoğunlukla, Trump'ın büyükelçiliği Kudüs'e taşıma kararını kabul etmemiş ve tüm ülkeleri Kudüs'te büyükelçilik kurmaktan kaçınmaya çağırmıştır. Karara 128 ülke lehte oy verirken 35 ülke çekimser kalmış ve ABD ve İsrail dâhil 9 ülke aleyhte oy kullanmıștır. Uluslararası toplum da ABD'nin bu konuda öncülügünü takip etmemiş ve elçiliklerini Kudüs'e taşımamıştır. Bugüne kadar ABD dışında büyükelçiliklerini Kudüs'e taşıyan ülkeler yalnızca Guatemala ve Kosova olmuştur (Reuters, 14 Mart 2020).

Son olarak 28 Ocak 2020'de Başkan Trump, o zamana kadarki en çarpıcı hamlelerinden birini yapmıș ve "Yüzyılın Anlașması" olarak adlandırdığı "Refaha Giden Barıș: Filistin ve İsrail Halklarının Yaşamlarını Geliştirmeye Yönelik Bir Vizyon" başlıklı bir plan açıklamıştır. Plan, gelecekte İsrail ve Filistin arasındaki müzakerelerde temel noktaları teşkil etmek üzere birtakım esaslar belirlemiştir. Bu plana göre İsrail, yerleşim yerleri ve Ürdün Vadisi'nin çoğu dâhil olmak üzere Batı Şeria'nın yaklaşık \%30'undan fazlasının egemenliğini elde edecekti. Filistinliler sonunda geri kalan topraklar üzerinde sınırlı bir egemenlik biçimi kurabilecekti. Filistin yönetimine bırakılan topraklar, hâlihazırda kendileri tarafından yönetilen bölgelerin yanı sıra geçmişte İsrail tarafından işgal edilip onların kontrolünde olan ilave bölgeleri içermekteydi (Kershner - Halbfinger, 31 Ocak 2020). 
Dolayısıyla İsrail, neredeyse tüm Kudüs üzerinde egemenliğe sahip olacak ve Filistinliler yalnızca İsrail güvenlik bariyerinin diğer tarafında bazı küçük Doğu Kudüs bölgelerini elinde tutabileceklerdi.

Öte yandan İsrail, Batı Şeria'nın tamamının güvenliğini sağlama görevini kalıcı olarak sürdürecek, ancak Filistinliler zamanla yönettikleri topraklarda daha fazla sorumluluğu üstlenebilecekti. Son olarak Filistinliler, başkenti Abu Deis veya yukarıda belirtilen Doğu Kudüs bölgeleri ile dıș mahalleleri arasında kalan bașka bir yer olmak üzere askerden arındırılmış bir devlete sahip olabileceklerdi. Bu devlet olma durumunun devamı, önümüzdeki dört yıl içinde önemli iç ve pratik zorlukları aşması ve belirli kriterleri karşılaması halinde devam edebilecekti. Bu kriterler arasında Hamas'ın Gazze'de silahsızlandırılması, bazı uluslararası girişimlerin ve şiddete yönelik mali teşviklerin sona erdirilmesi ve İsrail'in "Yahudi halkının ulus devleti" olarak tanınması yer almıștır (Farrell, 28 Ocak 2020).

Trump'ın "Yüzyılın Anlaşması" olarak adlandırdığı bu tasarı, İsrail'in Filistin topraklarında gerçekleştirdiği işgale bir meşruiyet kazandırma ve Filistinlilerin en temel haklarının görmezden gelinmesi girişimini yansıtmıştır. Anlaşma, İsrail'in 1967'de işgal ettiği Filistin topraklarının büyük kısmını ilhak etmesine izin vererek Filistinlilerin Batı Şeria, Gazze ve Doğu Kudüs'te bağımsız bir devlet kurma umutlarını yok etmeyi amaçlamıştır (Jaffe - Hoffman, 27 Ocak 2020). Dolayısıyla bu tasarı, İsrail'in Kudüs üzerinde tam bir hâkimiyet sağlaması gerektiği inancına yönelik aşamalı kaderci anlayış çerçevesinde Trump yönetiminin öncülüğünü yaptığı önemli dış politika hamlelerinden bir başkası olmuştur. Anlașmanın mahiyeti, Kudüs'ü ahir zamana ve klyamete dair senaryolarının merkez üssü sayan Evanjelik inancın tezahürlerini taşımıştır.

\subsection{Amerikan Büyükelçiliğinin Kudüs'e Taşınması Kararı: Evanjelizm Etkisi}

Donald Trump’ın İsrail büyükelçiliğini Kudüs'e taşıma kararı, “İsa'nın İkinci Gelişi” için ilk adım olarak İsrail'in Kudüs'ü tamamen kontrol etmesi gerektiğine inanan Evanjeliklerin uzun zamandır gerçekleşmesini arzuladıkları bir hareket olmuştur. Çünkü bu “Tanrı'nın Planı”nın bir parçası ve "İncil'in kehanetlerinden” olarak görülmüştür. Trump'ın Evanjelik danışmanlarından biri olan Robert Jeffress, Kudüs'ün, "tarih boyunca hem Yahudiler hem de Hıristiyanlar için büyük bir alakaya mazhar olduğunu" ve "İncil kehanetlerinin mihenk taşı olduğunu" söyleyerek "Kudüs'ün İsrail'e verilmesinin İncil'in bir emri ve Tanrı buyruğu" olduğunu" ifade etmiștir. Diğer önde gelen Evanjelik isimler de Trump'ın kararının "İncil'le ilgili" olduğunu ve Trump'ın bir "İncil kehanetini yerine getirdiğini" söyleyerek Başkan'a olan desteklerini belirtmiştir (Burke, 6 Aralık 2017). Dışişleri Bakanı Pompeo da kararı anarken dini referanslara ve kendi Evanjelik inancına atıf yapmıştır. Iowa'da katıldığı bir Evanjelik konferansta, Trump ekibinin ABD tarihindeki en İsrail yanlısı yönetim olduğunu ortaya koyarken ilk gerekçesi büyükelçiliğin Kudüs'e taşınması olmuştur (Rosenberg, 20 Temmuz 2020).

Başkan Trump'ın bu kararı almasında kendisine kampanya vaadini yerine getirmesi için baskı yapan Evanjelik lobilerin etkisi önemli bir paya sahip olmuştur. Evanjelik liderler, başkana bizzat lobi yapmışlar ve Christians United For Israel grubunun 135.000 üyesi Beyaz Saray'a, Başkan'ı ABD büyükelçiliğini Kudüs'e taşımaya çağıran e-postalar göndermişlerdir (Spector, 2019, 1-21). Trump'ın büyükelçiliğin taşınması kararını almasında etkili olmuş ve Evanjelik hareketin önde gelen figürlerinden biri olan John Hagee, bu kararın alınmasından önce Başkan'a tavsiyelerde bulunmak için 2017 yılında kendisiyle 2 saatlik bir görüşme gerçekleștirmiştir. 2018 yılında büyükelçiliğin açılış 
törenine Ivanka Trump ve eși Jared Kushner gibi isimlerle birlikte katılan Hagee, tören esnasında kürsüye çıkarak dini temaların yoğunlukta olduğu coşkulu bir konuşma yapmış ve "İsrail'in hala yaşadığını, bunu bütün 'İslamcıların' görmesi gerektiğini” belirterek meydan okumuştur (Bova, 9 Ağustos 2018). Trump yönetimi üzerindeki Evanjelik nüfuzu gösteren bu önemli karardan önce bazı Evanjelik liderler Trump'ı, Yahudileri Babil'in tutsaklığından kurtarmış olan M.Ö. 6. Yüzyılda yaşamış Pers imparatoru Cyrus'a benzetmiştir (Stewart, 31 Aralık 2018). Elçiliğin taşınması kararı, Trump'ın Yahudileri kurtarıp ana vatanları Kudüs'e dönmelerini sağlayan ve Süleyman Tapınağı'nı tekrar inşa eden Cyrus'la kıyaslanan pozisyonunu daha da güçlendirmiştir.

Öte yandan bin yıl önceci ve aşamalı kaderci anlayıș, son iki asırda Amerikan kurumlarını ve onlar üzerinden dünyayı etkileyen seküler anlayışın ürettiği evrenselci dile de atıf yaparak politikalarını rasyonelleştirme çabasındadır. Evanjeliklerin İncil'i yorumlayış biçiminin, Kutsal metinleri bağlamının dışında ele alarak kötüye kullanmak olduğu yönündeki suçlamalar (Amos, 5 Ocak 2018), Evanjelikleri savunma pozisyonuna itmiştir. Buna bağlı olarak Trump'ın en üst düzey Evanjelik danışmanlarından biri olan Johnie Moore, Evanjelikler arasında aşamalı kaderci görüşlerin etkisinin abartıldığını savunmuştur. Moore, elçiliğin taşınması kararından önce Beyaz Saray'da Trump ile yapılan görüşmelerde Kudüs'ün tartışıldığını fakat bunun "teolojik değil politik" bir tartışma olduğunu belirtmiştir. Dolayısıyla ABD büyükelçiliğinin Kudüs'e taşınma kararı "dini değil jeopolitik" bir hamle olarak yansıtılmıştır. Moore, Evanjeliklerin "normal insanlar" olduğunu ve "modern görüşler" taşıdığını belirterek apokaliptik fikirlerle bağlantılarının olmadığını iddia etmiştir. Bu çerçevede ABD Kongresi, 1995'te Kudüs'ü İsrail'in başkenti olarak tanıyan bir yasayı çıkarmış fakat o dönemden bu yana tüm Başkanlar bu yasadan feragat etmiștir. Buna göre Trump'ın hamlesi "adaletin bir tecellisidir ve şu an içinde bulunduğumuz gerçekliğin tanınmış olmasıdır". Kudüs hâlihazırda İsrail Devleti'nin yönetim merkezidir ve "İsrail dışında hiçbir ulusa başkentinin neresi olacağına dair bir dayatmada bulunulmamaktadır" (Amos, 5 Ocak 2018). Tüm bu söylemler, Evanjeliklerin dinî inançlarının yanına realist bakış açısını ve liberal-seküler kavramları sıkıştırıp, dinî dünya görüşleri ile çağdaş siyaset anlayışı arasında bağlantı kurarak politikalarını rasyonel kılma gayretlerine örnek teşkil etmektedir.

\section{Trump'ın İran Politikası: İsrail'in Güvenliği Meselesi ve Evanjeliklerin Etkisi}

Donald Trump'ın Başkanlık kampanyası süresince vaat ettiği en önemli politika değişikliklerinden biri, ABD'yi Kapsamlı Ortak Eylem Planı'ndan (KOEP) veya diğer adıyla İran Nükleer Anlaşması'ndan çekeceği olmuştur. Kampanya boyunca da anlaşmayı defalarca eleştirmiş ve 16 Haziran 2015'te Başkan adaylığını duyurduğu konuşmasında, Obama'nın KOEP'i imzalaması durumunda İsrail'in varlığının çok uzun sürmeyeceğini ve bunun bir "felaket" olacağını belirtmiştir. (Firstpost, [22 Mart 2016]).

Başkan olmasının ardından, Trump, İran'a yeni yaptırımlar uygulamış, gerekçe olarak da İran'ın yürüttüğü balistik füze testlerini ve bu ülkenin Ortadoğu'da terörü desteklediği iddialarını göstermiştir (Da Vinha, 2019, 280-289). Nükleer anlaşma ile ilgili ise, "İran'ın şimdi anlaşmaya uysa bile, kısa süre içinde tekrar nükleer bir silaha sahip olmanın eşiğine gelebileceğini" ve "mevcut anlaşmanın giderek çürüyen yapısı altında" ABD ve müttefiklerinin, İran'ın bir nükleer silah inșa etmesini durduramayacağını söylemiştir. Sonuç olarak Trump, ulusal güvenlik ekibinin itirazlarına rağmen, İran'ın anlaşmanın ruhuna uymadığını iddia ederek 8 Mayıs 2018'de anlaşmayı iptal etmiş ve İran'a yaptırımları yeniden uygulamaya koyduğunu duyurmuştur. (Da Vinha, 2019, 291-308). 
Başkan Trump, anlaşmadan çekilme nedeni olarak İran'ın dünyayı ve özellikle İsrail'i tehlikeye atmasını göstermiştir (Trump, 9 Mayıs 2018).

ABD, KOEP'den çekildiğinden bu yana, İran'ın petrol sektörünü hedefleyen yaptırımlar da dâhil olmak üzere Kasım 2018'de İran'a yönelik yaptırımların tam olarak yeniden uygulanmasını içeren bir "maksimum baskı" kampanyası başlatmıştır. (CNN, [14 Ocak 2020]). Trump, İran'ın “İsrail'e karşı amansız düşmanlığının, Tahran'a yönelik baskı politikasının en önemli faktörlerinden biri olduğunu” ifade etmiştir (Sanger - Kirkpatrick, 8 Mayıs 2018). Dışişleri Bakanı Pompeo, İran'ın "Batı medeniyetinin altını oymak, Ortadoğu'nun tek demokratik devleti, bir İncil ülkesi ve Yahudi vatanı İsrail'i yok etmek konusunda ciddi girişimlerde bulunduğunu" savunmuştur (Rosenberg, 29 Eylül 2020).

Bunlarla bağlantılı olarak aşamalı kaderci anlayış, Trump'ın İran'a yönelik uyguladığı politikaları Mesih'in dönüşünü başlatmanın bir yolu olarak görerek İran'ın “İncil tarihinde İran'ın oynayacağı büyük role" atıf yapmıştır. Buna göre İran, önceki bölümlerde detayları verilen, ahir zamanları başlatacak gelecekteki büyük savaşta İsrail'e saldıracak ülkelerden biri olacaktır (Boyer, 1994, 159-166). Örneğin Dışişleri Bakanı Mike Pompeo Mart 2019'da "Christian Broadcasting Network"e Kudüs'te verdiği bir röportaj sırasında, aşamalı kaderciler arasında popüler olan İran merkezli bir İncil hikâyesine atıf yapmıştır. Hikâyede, bir Pers kralına, kötü kalpli danışmanı Haman tarafından ülkesindeki Yahudileri katletmesi önerilir. Ancak kralın eşi, Yahudi Kraliçesi Esther onu bunu yapmamaya ikna eder ve halkını kurtarır. Pompeo, Trump'ın Yahudileri İran'dan kurtaran modern bir Esther olabileceğini düşünüp düşünmediği sorulduğunda, "Bir Hıristiyan olarak bunun mümkün olduğuna kesinlikle inanıyorum" demiștir (Bailey, 22 Mart 2019).

Keza Evanjelik lider John Hagee, “Trump'ın İran'la yüzleşmesini dört gözle beklediğini” ifade etmiștir. Trump, Hagee'nin kurucusu olduğu “Christians United for Israel”in lobi gününe, katılımcılara hitap etmeleri için en üst düzey mesai arkadaşlarını göndermiştir. Konferansta Pompeo orada bulunan kalabalığa yönelik bir konuşma yapmıştır (Bova, 9 Ağustos 2018).

Konuşması esnasında Pompeo, “Trump yönetiminin daha önceki yönetimlerin hiçbirinin yapmadığı şekilde gerçekleri dile getirdiğini ve bu gerçeğin kaynağının kendisinin de sürekli masasında açık tutup okuduğu İncil olduğunu" ifade etmiştir. Bu gerçeğin bir parçası olarak "İran İslam Cumhuriyeti'nin neden mağdur değil saldırgan olduğunu ve Amerika'nın bu kötülüğe karşı nasıl tüm dünyaya emsal olacak şekilde bir iyilik savaşçısı olarak mücadele verdiğini” anlatmıştır (Pompeo, 11 Ekim 2019).

Pompeo'nun bu sözlerinde aşamalı kaderciliğin "iyiler ve kötüler”, "Şeytan'ın hizmetinde olanlar" ve "İsa'nın hizmetinde olanlar" olarak dünyayı iki ana cepheye ayıran anlayışının esintileri bulunabilir. Buna göre çatışma, Tanrı'nın seçmiş olduğu halk ile o halkı bütünüyle yok etme peşinde olan fanatik bir düşman arasındadır ve bu sıfır toplamlı bir rekabet olarak görülmektedir.

Öte yandan gerek Körfez ülkeleri gerekse İsrail, ABD'nin İran'a yönelik stratejisine tam destek vermişlerdir. ABD ve bölgedeki müttefiklerinin çabalarını birleştirerek Tahran'ın saldırılarının ve genişlemeci politikalarının engellenmesi gerektiğini savunurken tüm bölge ülkelerini Amerikan liderliğine tabi olmaya çağırmışlardır. ABD’nin İran'a yönelik uygulayacağı politikalara sağlanacak bir Arap desteği Evanjelikler için büyük önem arz etmiştir. Dolayısıyla Trump yönetimi üzerindeki Evanjelik nüfuz ve perde arkasındaki aşamalı kaderci anlayıș, ABD’nin İran'a yönelik şiddetli baskı politikası ve Körfez ülkeleriyle İsrail arasındaki ilişkileri geliştirme çabalarının göze çarpan unsurlarından biri olarak dikkat çekmektedir. Keza aşağıda ayrıntılarına değinilecek olan Evanjeliklerin 
Körfez ülkelerinde gerçekleștirdiği ve Abraham Antlaşması'nın de zeminini hazırlayan diplomatik çabalarda vurguladıkları en önemli husus, İran tehdidine karşı Körfez ülkelerinin iş birliğine duyulan ihtiyaç olmuştur.

\section{1.İsrail ile Körfez Ülkeleri Arasında Gelişen İlişkiler}

\subsection{1.İsrail-BAE Anlaşması}

13 Ağustos 2020'de ABD Başkanı Donald Trump, İsrail'in körfez ülkeleriyle yıllardır yürüttüğü gizli temasları, BAE ve İsrail arasında resmi ilişkilerin başlamasını öngören bir anlaşma ile dünya kamuoyuna duyurmuştur. BAE, Mısır ve Ürdün'den sonra İsrail'i tanıyan üçüncü Arap devleti olmuştur. Antlaşma, İsrail'in işgal altında tuttuğu Batı Şeria'da ilhak planlarını askıya almayı kabulünü içermekte ve Orta Doğu'da barış çabalarını ilerleteceğini belirtmektedir. Her iki ülkenin de karşılıklı büyükelçi değişimine başlaması ve turizm, eğitim, sağlık, ticaret ve güvenlik gibi bir dizi alanda iş birliğine gitmesi öngörülmüştür (Landau, 16 Eylül 2020).

İsrail'in BAE ile ilişkileri, diğer körfez ülkelerine kıyasla geçmişten bu yana daha kapsamlı ve kamuoyuna açık bir nitelik arz etmiştir. Üst düzey temaslar zaten rutin haline gelmişti. Örneğin İran ile P5+1 ülkeleri arasında Kapsamlı Ortak Eylem Planı'nın (KOEP) imzalanmasının ardından Netanyahu, İran'la nasıl mücadele edileceği konusunda görüş alışverişinde bulunmak üzere 2015'te, Kıbrıs'ta Emirlik liderleriyle bir araya gelmiști (Entous, 18 Haziran 2018). Keza Aralık 2019'da ABD, ülkeler arasında bir saldırmazlık paktının da tartışıldığı ve temel olarak İsrail ile BAE arasında İran'a karşı koordinasyon sağlamak amacıyla düzenlenen gizli bir üçlü toplantıya ev sahipliği yapmıştı (Middle East Eye, 4 Şubat 2020).

Şubat 2019'da Varşova'da düzenlenen ABD öncülüğündeki "İran karşıtı" konferansın ardından, İran'a karşı iş birliğini güçlendirmek için aynı yıl içinde ABD, İsrail ve BAE arasında üçlü bir forum düzenlenmişti (Wintour - Holmes, 14 Şubat 2019). Dolayısıyla İsrail'le ilişkiler her ne kadar ulusal basında görünürlük kazanmamışsa da, BAE'de resmi bir tabu olma vasfını yitirmiștir. Çünkü her iki ülke de ortak bir gündeme sahiptir. İsrail'e yönelik olumsuz duyguların, İran'dan gelen tehdide karşı paylaşılan ortak çıkarları gölgelemesine müsaade edilmemesi gerektiği anlayışı hâkim olmuştur (Wintour Holmes, 14 Şubat 2019). Sonuç olarak iki ülke zaten birbirleriyle bir yakınlaşma süreci içine girmişti. Bu anlaşmayla İsrail'in diğer Körfez ülkeleriyle de benzer anlaşmalar yapmasının ve uzun süreli iş birliğinin önünü açacak bir temel atılmıştır.

Anlaşmayı incelediğimizde İsrail'in daha kazançlı olduğu görülmektedir. Netanyahu bir TV kanalına yaptığı konuşmada "Batı Şeria'nın ilhak planlarının sadece ertelendiğini, ancak hala masada olduğunu" söylemiştir (Aljazeera, 3 Ağustos 2020). Bu durum Filistin'in ve hatta BAE'nin bu normalleşme sürecinden ciddi kazanımlarının olmadığını göstermektedir. İkinci olarak bu anlaşma, Filistin meselesi ve Batı Şeria'nın ilhakı meselesinden çok İran ile ilgili görünmektedir. Hem BAE hem de İsrail'in stratejik hedeflerinin başında bölgedeki İran etkisini sınırlandırılması gelmektedir. Filistin davası artık Arapların dış politikalarında merkezi bir yer işgal etmemektedir. Bölge ülkeleri, karşılaştıkları yeni meydan okumalar, tehditler ve sorunlar ışığında öncelik listelerini değiștirmiş görünmektedir. İran, Hizbullah ve diğer milis gruplar, körfez ülkeleri tarafından ulusal güvenliklerine yönelik başlıca tehdit olarak algılanmaktadır. Nitekim bu sürecin öncülüğünü ve arabuluculuğunu yapan Trump yönetiminin Ortadoğu politikasına genel olarak bakıldığında da, İran ve müttefiklerine karşı ittifak arayışının bu anlaşmanın temel zemini olduğu görülmektedir. 


\subsubsection{Suudi Arabistan-İsrail Ekseni ve Ortak İran Tehdidi Algısı}

Abraham Antlaşması'na kadar İsrail ile Suudi Arabistan liderliğindeki Körfez İş birliği Konseyi'nin altı üyesi arasında resmi bir ilișki olmamıștır. Ancak 2002 yılında İran'ın Natanz'daki gizli uranyum zenginleştirme tesisinin ortaya çıkması ve ABD’nin 2003'te Irak'ı işgali, İran'ı güçlendirerek bölgedeki nüfuzunu arttırmıştır. Eş zamanlı olarak bu ülkenin Ortadoğu'da güçlenen nüfuzuna ve planlarına yönelik ilgi de artmaya başlamıştır (Lewis, 3 Mart 2015).

2004 yılında Ürdün Kralı II. Abdullah, bölgede bir "Şii Hilalinin" ortaya çıktığını söylemiştir. 2009 yılının Eylül ayında ABD, İngiltere ve Fransa, İran'ın Kum kenti yakınlarındaki Fordow'da gizli, ikinci bir uranyum zenginleştirme tesisi inşa ettiğini duyurmuş ve bu gelişme Körfez ülkeleri tarafından İran'dan algılanan tehdidin şiddetini arttırmıştır (Black, 19 Mart 2019). 2011'de Arap Baharı'nın başlamasıyla birlikte, Mısır'da Hüsnü Mübarek'in devrilmesi Suudi Arabistan ve BAE yönetimlerinde endişelere yol açmıştır. Obama'nın bu gelişmelere rıza göstermesi, İslamcı hareketlere karşı uzun süredir devam eden düşmanlığı güçlendirmiştir. Suriye'deki iç savaşın adım adım kötüye gitmesi ve 2012 'den sonra İran ve Hizbullah'ın bu ülkede oynadığı artan rol, İsrail ile Körfez ülkeleri arasındaki yakınlaşmayı etkileyen diğer faktörler olmuştur (Cooper Worth, 25 Eylül 2012).

Hasan Ruhani'nin Cumhurbaşkanı seçilmesinin ardından, İran ile nükleer müzakerelerin hızlanması ve 2013'te Cenevre'de geçici bir anlaşmaya varılması İsrail Başbakanı Netanyahu'nun tepkisine yol açmış ve nükleer bir İran'ın yarattığı tehdidin başka bir takım "tarihi düşmanlıkların üstesinden gelme ve yeni ilişkiler, yeni dostluklar kurma fırsatı" verdiğini belirtmiştir (IMFA, Ekim 2013). İsrail, ortak İran tehdidine karşı Arap dünyasıyla iş birliğini arttırmayı arzulamıştır.

Aynı dönemde Suudi Arabistan ve BAE, İran'a karşı harekete geçmesi için ABD üzerindeki baskıyı arttırmak maksadıyla İsrail'le mutabık kalmışlardır (Entous, 18 Haziran 2018). Nitekim Körfez ülkeleriyle İsrail arasındaki iş birliği, büyük ölçüde Obama'nın ikinci Başkanlık döneminde artmıştır. Obama yönetiminin dışladığı Suudi Arabistan ve İsrail, buna tepki olarak kendi aralarındaki ilişkileri derinleștirmiștir. Eski bir İsrailli yetkili de aynı noktaya işaret etmiş ve Obama yönetiminin İsrail ile BAE ve Suudiler arasındaki ilişkilerin gelişmesine fark etmeden de olsa çok önemli katkılarda bulunduğunu söylemiştir (Black, 19 Mart 2019).

İsrail'in 1948'den beri temel arzusu, Arap devletleriyle ihtiyatlı ilişkiler kurarak Filistinlileri zayıflatmak olmuştur. Geçmişte Körfez ülkeleri, Arap ve Müslüman kamuoyunun göstereceği tepkiden çekindikleri için İsrail ile bağlantı kurmaktan kaçınmıştır. Bu durum değişirken, İsrailli politikacılar ve yetkililer Arap devletleri ile İran'a ve teröre karşı mücadele konusunda istihbarat koordinasyonundan söz etmeye başlamışlardır. 2010 yılında dönemin Mossad Direktörü Meir Dagan, İran'ı hedefleyen operasyonlar yapmak amaciyla Körfez ülkeleriyle gizli ittifaklar kurma stratejisine dayanarak Suudi Arabistan'ı ziyaret etmiştir (Pfeffer, 26 Temmuz 2010). 2017 Kasım'ında İsrail Silahlı Kuvvetleri Genelkurmay Başkanı Gadi Eisenkot'un Suudi Arabistan'a İran ile ilgili istihbarat paylaşımı teklif ettiği ortaya çıkmıştır (Aljazeera, 16 Kasım 2017). Eski bir üst düzey $\mathrm{ABD}$ diplomatı, "Bu ülkelere giden İsrail istihbarat personelinin Arap ülkelerinin liderleriyle buluştuğunu ve birbirlerini oldukça iyi tanıdıklarını" söylemiştir (Black, 19 Mart 2019). Obama'nın başkanlığı döneminde Dışişleri Bakanı olan Hillary Clinton “BAE ve Suudi Arabistan'ın İran etkisine karşı koymak için Mossad'la birlikte çalıştıklarını bildiğini” belirtmiştir (Entous, 18 Haziran 2018). Tüm bu iş birliğini Mossad 
yöneticisi David Meidan, "İsrail ve Körfez ülkeleri aynı gemideydi" ifadeleriyle yorumlamıştır (Black, 19 Mart 2019).

Muhammed bin Salman, savunma bakanı ve veliaht prens yardımcısı olarak atanıp ardından Haziran 2017'de veliaht prensliğe terfi ettirildikten sonra İsrail-Suudi iş birliğinin kapsamı genişlemiştir. Veliaht prensin 2018 baharında ABD'ye yaptığı üç haftalık seyahatte İsrail hakkında verdiği mesajlar ve İsrail yanlısı Amerikalı Yahudi liderlerle bir araya geldikten sonra "Filistinlilerin Trump'ın önerilerini kabul etmesi" ya da "susup şikâyet etmeyi bırakması" gerektiği yönündeki söylemleri yeni bir dönemi işaret etmiştir (Aljazeera, 30 Nisan 2018). Salman "Filistin meselesinin ne hükümeti ne de Suudi halkı için bir öncelik olmadığını" ve "İran gibi, ele alınması gereken çok daha acil ve daha önemli konular" olduğunu açıkça belirtmiştir (Fars News Agency, 30 Nisan 2018). Dolayısıyla Salman'ın yükselişiyle birlikte İsrail'e yönelik olumlu, İran'a yönelik ise düşmanca tutumlar artmaya başlamıştır.

Öte yandan İsrail'le ilişkilerin normalleşmesi yolunda BAE'yi takip eden ilk ülke Bahreyn olmuştur. Öncesinde Bahreyn Kralı Hamad bin İsa Al Halife, İsrail-BAE anlaşmasını bölgede "barış için tarihi bir adım" olarak nitelendirmiştir (Düz, 21 Eylül 2020). Bu durum Suudi Arabistan'ın da konuya sıcak yaklaştığının işaretlerini taşımaktadır. Müteakiben Bahreyn'in BAE'ye iştirak etmesi, Suudi Arabistan'ın onayı olmadan böyle bir adım atamayacağı için ayrıca önemli olmuştur.

Bundan sonra Başkan Trump’ın kıdemli danışmanı ve damadı Jared Kushner, "bölgedeki birçok liderin artık Filistin'i beklemekten yorulduğunu ve İsrail gerçekliğini tanımak istediğini" belirtmiştir. Kushner, "Suudilerin harekete geçmeden önce normalleşme sürecinin nasıl işlediğini görmek için beklediğine inandığını" ifade etmiş ve "nihayetinde İsrail ile Suudi Arabistan arasında da bir normalleşme sürecinin kaçınılmaz" olduğunu söylemiştir (Ignatius, 11 Eylül 2020).

Bahreyn ve BAE önemli bir başlangıç niteliği taşısalar da, bölgedeki asıl büyük değişimin Suudi Arabistan üzerinden yaşanması beklenmektedir. İran'ın yükselişi, Arap Baharı sonrasında otokratik rejimlerin artan güvensizlik hissi ve ABD ile bağlantılarının kesileceği korkusu, Arap ülkelerinin İsrail'le olan ilişkilerinin gelişmesinde rol oynamıştır. Ancak Abraham Antlaşması ile gelişen sürecin temelinde esas olarak İran'a karşı birlikte mücadele anlayışı yatmaktadır.

\subsubsection{Körfez Ülkelerine Yönelik Evanjelik Diplomasi}

Evanjelikler, İsrail-BAE anlaşmasına giden yolda oldukça etkili olmuştur. Anlaşmadan önce, Mayıs 2020'de Netanyahu, en geç Temmuz'a kadar Batı Şeria'da ilhak operasyonunun başlayacağını ilan ederken Evanjelikler için İsrail'in Arap devletleriyle normalleşme sürecine girmesi, "çorak tepelerin durumunu değiştirmekten” çok daha önemli görülmüştür (Jaffe - Hoffman, 13 Ağustos 2020). Evanjelik lider Rosenberg üst düzey bir $\mathrm{ABD}$ yetkilisiyle yaptığı görüşmede, İsrail ile $\mathrm{BAE}$ arasında bir barıș anlaşmasının "ilhak girişiminden çok daha önemli, tarihi, stratejik ve oyunun kurallarını değiştirecek" niteliğe haiz olduğunu öne sürmüş ve yönetime bu rotayı güçlü bir şekilde takip etmesi için baskı yaptığını belirtmiştir (Rosenberg, 13 Ağustos 2020).

$\mathrm{Bu}$ görüşlerin olgunlaşmasında, 2018 yılında Evanjelik liderlerden oluşan bir delegasyonun BAE'ye gerçekleştirdikleri ziyaret ve Emirlik yetkilileriyle yapılan görüşmeler, önemli bir zemin teşkil etmiştir. Bu temaslarda "İsrail ile BAE arasındaki ilişkilerin normalleşmesi” hakkında görüş alışverişi yapılmıştır. Sonrasında Rosenberg, BAE Dışişleri Bakanı ve Büyükelçisiyle artan İran tehdidinden, bir "Arap NATO'su" 
yaratma planlarına, din özgürlügünden İsrail-Filistin barış sürecine çeşitli konuları tartışmak üzere birçok kez bir araya gelmiş ve katıldığı her toplantıda “BAE'nin İsrail'le bir barış anlaşması üzerinde çalıștığı izlenimi aldığını" ifade etmiştir (Rosenberg, 13 Ağustos 2020). Dolayısıyla Evanjelik gruplar, gerek Arap ülkelerinin liderleriyle bir araya gelerek, gerekse de Amerikan yönetimine söz konusu eğilimin sürdürülmesi için telkinlerde bulunarak, bu anlaşmanın alt yapısına ciddi katkılar yapmıştır. Nitekim Evanjelik delegasyon bölge turunu tamamladıktan sonra Donald Trump'ın Evanjelik Danışma Konseyi Başkanı Johnnie Moore, kısa süre içinde İsrail ile Sünni Körfez ülkeleri arasında barıș öngördüğünü söylemiş ve öngörüsü gerçekleşmiştir (Jaffe - Hoffman, 13 Ağustos 2020).

Moore aynı zamanda, antlaşmanın ardından Bahreyn gibi diğer Arap ülkelerinin de BAE'nin izinden gideceğini öngördüğünü ifade etmiştir. Bahreyn 11 Eylül 2020'de bu beklentiyi doğrulamıştır (Jaffe - Hoffman, 13 Ağustos 2020). BAE Veliaht Prensi Muhammed Bin Zayed, Ekim 2018'de kendisini ziyaret eden Evanjelik delegasyona İsrail ile barış yapmaya hazır olduğunu söyledikten sonra, özel bir ilgi görmeye başlamış ve ABD medyası BAE'de adeta bir "Ilımlılık Hazinesi" keşfetmiştir. Ardından "Bir Arap ülkesinde özgürlügün nasıl doğduğuna" ve "BAE’nin nasıl etkileyici bir dini hoşgörü modeli yarattığına" dair söylemler artmaya başlamıştır (Mitchell, 31 Ekim 2018). Evanjelikler bir kez daha liberal-seküler kavramlara atıf yaparak politikalarını meşrulaştırmaya çalışmış, özgürlük, adalet, dini hoşgörü ve barış içinde bir dünya için çabalama misyonu taşıdıkları mesajını vermiştir.

2018 yılında BAE’yi ziyaret eden Evanjelik delegasyon daha sonra bölge genelinde birçok toplantıya katılmıștır. Bu kapsamda Prens Salman, 2019 yılında Cidde'de Amerikalı Evanjelik liderlerden oluşan bir heyetle bir araya gelmiştir (Ahmed, 19 Ekim 2019). Suudi Arabistan'ın Washington Büyükelçiliği tarafından yapılan açıklamada, iki tarafın "bir arada yaşamayı teşvik etme" ve "aşırılıkçlıkla mücadele" üzerine görüş alışverişinde bulundukları söylenmiştir. Buluşma hem Suudi hem de ABD hükümetleri tarafından desteklenmiş ve görüşmede ayrıca "Suudi Arabistan'ın geleceğine dair" görüş alışverişinde bulunulmuştur. Ele alınan konular arasında terörizm, din özgürlüğü, insan hakları, Ortadoğu'daki jeopolitik durum ve barıș süreci yer almıştır (Batrawy, 11 Eylül 2019). Evanjelik delegasyon içindeki isimlerden biri olan Larry Ross, "İsa adına uzlaşma elçileri" olarak orada bulunduklarını ifade etmiştir (Boorstein, 2 Kasım 2018). Öte yandan bu ziyaret 11 Eylül tarihine denk gelmiştir ve heyetin lideri Joel C. Rosenberg, bu zamanlamaya yönelik eleştirileri "18 yıl önce Usame Bin Ladin, El Kaide ve şiddetli cihadın radikal teolojisinin içinden çıktığı Suudi Arabistan artık yok. Amerikalıların birçoğunun bilmediği köklü değişiklikler yaptılar. Suudi Arabistan'da devam eden reformların çoğu gerçek, tarihi ve cesaret verici" diyerek yanıtlamış ve Suudi Arabistan'ın hâlihazırda gitmekte olduğu rotayı ve ileriye yönelik nasıl bir strateji izlemesi gerektiğini tartışmak için en uygun zamanı seçtiklerini belirtmiştir. Suudi Arabistan, "radikal İslamcı terörizme ve yükselen İran tehdidine karşı savașta Amerika'nın en önemli stratejik müttefiklerinden" biri olarak görülmüştür (Mitchell, 13 Eylül 2019).

2018'de Cidde'yi ziyaret eden heyet içinde Trump'ın Evanjelik danışmanlarından Johnnie Moore da yer almıştır ve döndükten sonra, Salman'ın reformlarını ve Suudilerin "Ilımlı İslam yönelimine" olan desteğini ifade etmiştir. 2019'daki ikinci ziyaretten sonra Moore bu kez övgüsünde çok coşkulu olmasa da delegasyonun Suudi Arabistan'daki gelişmelerden memnun olduğunu belirten bir açıklama yapmıştır (Henne, 13 Eylül 2019). Dolayısıyla Evanjelikler, 11 Eylül 2001 'de ABD'ye yapılan terör saldırılarından yıllar 
sonra, bilhassa Evanjelik delegasyonun 2018'deki ziyaretinin ardından Suudi Arabistan'ın kapsamlı ekonomik, sosyal, kültürel ve dini reformlardan geçtiğini savunmaktadır.

Önceki bölümde örneklerle gösterildiği üzere her iki taraf da İran'ı varoluşsal bir tehdit olarak gördügü için İsrail ve Suudi Arabistan'ın gizli güvenlik bağları olduğu uzun zamandır bilinmektedir ancak Suudi Arabistan İsrail Devleti'ni resmi olarak hala tanımamaktadır. Bununla birlikte, İsrail ile Birleşik Arap Emirlikleri arasında yapılan anlaşmadan sonra diğer körfez ülkelerinin ve nihayetinde Suudi Arabistan'ın bu sürece katılacağı beklentisi uyanmıştır.

Esasında Suudi Arabistan, Hristiyanlar da dâhil olmak üzere gayrimüslimlere karşı davranışları, Batı dünyasında muhtelif tartışmalar yaratmış bir ülkedir. Örneğin "Açık Kapılar Dünya İzleme Listesi" raporuna göre Hristiyanların en çok zulüm gördüğü ülkelerden biridir (Casper, 15 Ocak 2020). Tarih boyunca Evanjeliklerin başlıca dış politika öncelikleri arasında uluslararası din özgürlüğünün yer aldığı göz önünde tutulduğunda, dünyadaki en baskıcı devletlerden biri karşısında bu derece olumlu bir tavır takınılması çelişkili görünmektedir. Ancak bu tutarsızlıkta tarihi bir devamlılık gözlemlenebilir. Kendisi de bir Evanjelik olan Carter'ın başkanlığından itibaren ABD, tüm dünyada insan haklarını teşvik etme şeklinde bir politika anlayışı benimsemişti. Buna rağmen Soğuk Savaș konjonktüründe dönemin ABD yönetimleri ve önde gelen Evanjelik isimler, "her ülkede insan hakları ve demokrasinin desteklenmesinin Komünizmi getirebileceği" tehlikesini gerekçe göstererek Güney Amerika ve Ortadoğu'da otoriter yönetimlere destek vermişlerdir. Bugün de aynı durum geçerliliğini korumaktadır. Evanjeliklerin nazarında Suudilerle dinler arası diyalog politikaları, İran'a karşı mücadele ve İsrail devletine daha fazla Arap desteği için bir firsat olarak görülmektedir.

\section{Sonuç}

Bu çalışma, bin yıl önceci aşamalı kadercilik anlayışını benimseyen evanjelik grupların Donald Trump yönetimi döneminde Amerikan dış politikasının oluşumunu nasıl etkilediklerini ve evanjelizm inancının ve bu inancl benimseyen grupların savunup destekledikleri çeşitli dış politika girişimlerine odaklanmıştır. Bu noktada evanjeliklerin iç ve dış politikada bir baskı grubu olarak çıkar algılarını açıklama, özel olarak ilgilendiği dış politika alanlarından bazılarını tanımlama, belirli kararları etkilemek ve izlemek için kullandığı yöntemleri analiz etme ve Evanjelik hareketin Başkan Trump ve kabinesindeki diğer isimlerle olan etkileşimleri ve bağlantılarını gözlemlemeye çalışmıștır. Amerikan dış politikasına yönelik karar verici konumda olan figürlerin Evanjelik grupların bu çabalarına ne derece ilgi gösterdiği ve dolayısıyla bu grupların önceliklerinin ne ölçüde dikkate alındığını göstermiştir. Bin yıl önceci aşamalı kaderci itikada bağlı evanjelik grupların argümanlarının ABD'nin Ortadoğu politikasını ve bu vesileyle genel olarak uluslararası ilişkileri gerçekten etkilemeyi başardığı görülmüştür.

2016 yılı ABD Başkanlık seçimlerinde beyaz Evanjelik seçmen, yüzde 81 gibi yüksek bir çoğunlukla Donald Trump'a oy vermiştir. Esasında Donald Trump, Evanjelik ahlak anlayışı bakımından hiç de uygun bir aday gibi gözükmese de bu seçmen grubu, Trump için önceki dört Cumhuriyetçi adaya kıyasla daha yüksek bir oranda oy kullanmıştır. Seçimlerden sonra da Evanjeliklerin Trump yönetimine olan desteği sürmüş ve 2018 ara seçimleri sırasında Evanjelikler, 2016 yılında Donald Trump'a vermiş oldukları desteğin de üstüne çıkan bir oy oranıyla Cumhuriyetçi adayları desteklemiştir (The Economist, 28 Şubat 2019). Buna bağlı olarak Evanjelikler hem Trump'ın seçmen tabanının dini çekirdeğini oluşturmuş hem de izlediği dış politikalarda önemli ölçüde etkili hale gelmiștir. 
Trump, 2016 seçimlerinde ülkedeki en etkili evanjelik liderler tarafından desteklenmiştir. Amerikan tarihinin en önemli evanjelik figürlerinden biri olan Billy Graham'ın oğlu Franklin Graham, Donald Trump'ın kampanyasının ilk destekçilerinden biri olmuştur (Griswold, 11 Eylül 2018). Graham'ın yanı sıra Moral Majority organizasyonun kurucusunun oğlu Jerry Falwell Junior, Ocak 2016'da Trump'a yönelik desteğini belirterek onun “ABD'yi yeniden o eski büyük ve ihtişaml günlerine götüreceğine inandığını" belirtmiştir (Costa - Johnson, 26 Ocak 2016). Trump, göreve başladıktan sonra gerçekleştirdiği icraatlar ile Falwell tarafından "Evanjeliklerin rüya başkanı" olarak adlandırılmıștır (Gerson, 1 Mayıs 2017).

Donald Trump'ın dış politikaya yönelik yaklaşımı her ne kadar bu evanjelik gruplarla aynı dini ve ahlaki hassasiyete dayanmasa da bu zihniyetin seküler bir uyarlaması olarak benzer kaygılara vurgu yapmıştır. Trump'ın dış politikaya yaklaşımı ve bu politikaların oluşumunda hükümet aygıtlarını kullanış tarzı kendine özgü olsa da, iç ve dış meselelere olan yaklaşımı Evanjelik grupların hassasiyetleriyle uyumlu bir görüntü arz etmiştir.

Trump daha önce birçok ABD Başkanı'nın söz vermesine rağmen tutamadığı bir kampanya vaadini yerine getirmiş ve Kudüs'ü İsrail'in başkenti olarak tanımıştır. Ardından ABD, İsrail Büyükelçiliği'ni Kudüs'e taşımıştır. İsa'nın ikinci gelişi için İsrail'in Kudüs'ü tamamen kontrol etmesi gerektiğini düșünen evanjelikler bakımından bu hareket, kritik önemi haiz olmuştur. İkinci olarak, İran'a yönelik baskı ve yaptırımları yoğunlaştırmış ve 26 yıllık aradan sonra ilk kez bir Arap devletinin İsrail ile barış yapmasına öncü olarak İsrail ve BAE arasındaki barıș antlaşmasına arabuluculuk etmiştir. Evanjelikler için bu tür bir barış antlaşması, Ortadoğu'daki jeopolitik dengeleri İsrail lehine değiştireceği sebebiyle stratejik nitelikte olmuştur. Dolayısıyla bir taraftan Trump yönetimine bu siyaseti benimsemesi için baskı yapmışlar diğer yandan da oluşturdukları çeşitli delegasyonlar aracılığıyla Körfez ülkelerini ziyaret ederek bu anlaşmanın alt yapısını hazırlamışlardır. İsrail-BAE antlaşmasının imzalanmasında en temel faktörlerden biri İran ve müttefiklerine karşı beslenen ortak düşmanlık olmuştur. İran'ın aşamalı kaderci anlayış çerçevesinde oynadığı rol ve İncil'de yer alan İran merkezli birçok hikâye, ABD yönetimi ve çeşitli evanjelik liderler tarafından günlük politik gelişmeler kapsamında ele alınmış, Trump yönetiminin bu ülkeye yönelik baskı politikaları meşrulaştırılmaya çalışılmıştır.

Sonuç olarak bu makale, evanjeliklerin Trump'ın başkanlık dönemi boyunca dış politika kararlarına katılımını inceleyerek ilgili literatürün gelişimine katkıda bulunmaya çalışmıştır. İncelememizde ulaştığımız bulgular, İsrail'deki ABD büyükelçiliğinin Kudüs'e taşınmasında, Trump yönetiminin öncülügünü ettiği İsrail-BAE anlaşmasında ve daha geniş anlamda Körfez ülkeleri ile İsrail arasındaki iş birliğinin boyutlarını güçlendirecek politikaların teşvikinde aşamalı kaderci inancı benimseyen Evanjelik grupların ve Trump yönetimindeki Evanjelik figürlerin önemli bir paya sahip olduğunu göstermektedir. 


\section{Kaynakça}

Ahmed, Akbar Shahid. "Khashoggi's Murder Should Have Made Saudi Arabia A Pariah. 7 Men Made Sure That Didn't Happen”. The Huffington Post (19 Ekim 2019). https://www.huffpost.com/entry/saudi-sevenkhashoggi_n_5d975e49e4b02911e11a38b1.

Aljazeera. "Israel 'willing to share' Iran intelligence with Saudis" (16 Kasım 2017).

https://www.aljazeera.com/news/2017/11/16/israel-willing-to-share-iranintelligence-with-saudis.

Aljazeera. “MBS: Palestinians should 'accept Trump proposals or shut up'” (30 Nisan

2018). https://www.aljazeera.com/news/2018/4/30/mbs-palestinians-should-accepttrump-proposals-or-shut-up.

Aljazeera. "Netanyahu says West Bank annexation plans still 'on the table" (13 Ağustos 2020). https://www.aljazeera.com/news/2020/8/13/netanyahu-says-westbank-annexation-plans-still-on-the-table.

Amos, Owen. "Why do US evangelicals support Trump's Jerusalem policy?". BBC (5 Ocak 2018). https://www.bbc.com/news/world-us-canada-42402350.

Bailey, Sarah Pulliam. "Pompeo: Perhaps Trump is, like the Bible's Esther, meant to save the Jewish people from Iran", The Washington Post (22 Mart 2019), https://www.washingtonpost.com/religion/2019/03/22/pompeo-perhapstrump-is-like-bibles-esther-meant-save-jewish-people-iran/.

Ballmer, Randall. Mine Eyes Have Seen the Glory: A Journey into the Evangelical Subculture in America. 4.bs. Oxford: Oxford University Press, 2006.

Batrawy, Aya. "US Christian evangelical delegation meets Saudi crown prince", The Associated Press (11 https://apnews.com/article/e7f10269e60b46dabe31c455fa04017e.

Bird, Michael F. Evangelical Theology: A Biblical and Systematic Introduction. Grand Rapids: Zondervan Academic, 2013.

Black, Ian. "Why Israel is quietly cosying up to Gulf monarchies", The Guardian (19 Mart 2019). https://www.theguardian.com/news/2019/mar/19/why-israel-quietly-cosying-up-togulf-monarchies-saudi-arabia-uae

Boettner, Loraine. The Millennium. Philipsburg, New Jersey: P\&R Publishing, 1991)

Boorstein, Michelle. “Trump's evangelical advisers meet with Saudi Crown Prince and discuss Jamal Khashoggi's murder, "human rights," spokesman says". The Washington Post (2 Kasim https://www.washingtonpost.com/religion/2018/11/01/it-is-our-desire-lift-upname-jesus-trumps-evangelical-advisers-meet-with-saudi-crown-princemohammed-bin-salman/.

Breger, Marshall, Hammer, Leonard. Contested Sites in Jerusalem. New York: Routledge, 2018.

Bova, Gus. "Under Trump, Islamophobic Pastor John Hagee's Star Rises Again". Texas Observer (9 Ağustos 2018). https://www.texasobserver.org/trump-pastor-johnhagee-texas-jerusalem/. 
Boyer, Paul. When Time Shall Be No More: Prophecy Belief in Modern American Culture. Cambridge: Belknap Press, 1994).

Burke, Daniel. "Why evangelicals are 'ecstatic' about Trump's Jerusalem move". CNN (6 Aralık 2017), https://edition.cnn.com/2017/12/06/politics/americanevangelicals-jerusalem/index.html.

Carter, Jimmy. Our Endangered Values: America's Moral Crisis. Newyork: Simon \& Schuster, 2006.

Casper, Jayson. “The Top 50 Countries Where It's Hardest to Be a Christian”.

$\begin{array}{llll}\text { Christianity } & \text { Today } & \text { Ocak } & \text { 2020). }\end{array}$ https://www.christianitytoday.com/news/2020/january/top-christianpersecution-open-doors-2020-world-watch-list.html.

Cavari, Amnon, Freedman, Guy. From Bipartisan Agreement to Electoral Contest:

Israel in US Elections. Lanham, MD: Lexington Books, 2017.

Cavari, A. Freedman, Guy. Partisan Cues and Opinion Formation on Foreign Policy.

American Politics Research, 47 (1), 29-57, 2019.

Cavari, Amnon, Nyer, Elan. From Bipartisanship to Dysergia: Trends in Congressional Actions Toward Israel. Israel Studies, c.19, s.2 (1997): 7-48.

Chersterton, Gilbert K. What I saw in America. California: Create Space, 2016.

Cooper, Helene - Worth, Robert F. “In Arab Spring, Obama Finds a Sharp

Test". The New York Times (25 Eylül 2012), https://www.nytimes.com/2012/09/25/us/politics/arab-spring-proves-aharsh-test-for-obamas-diplomatic-skill.html.

Costa, Robert, Johnson, Jenna. “Evangelical leader Jerry Falwell Jr. endorses

Trump“. (The Washington Post (26 Ocak 2016), https://www.washingtonpost.com/news/postpolitics/wp/2016/01/26/evangelical-leader-jerry-falwell-jr-endorses-trump/.

Council on Foreign Relations. "The Reagan Plan: U.S. Policy for Peace in the

Middle East" (1 Eylül 1982). https://www.cfr.org/israel/reagan-plan-us-policy-peacemiddle-east/p14140.

Da Vinha, L. Competition, Conflict, and Conformity: Foreign Policy Making in the First Year of the Trump Presidency. Presidential Studies Quarterly, 49(2), 280-309, 2019.

Düz, Zehra Nur. “Bahrain's king: Deal with Israel 'historic step”'. Anadolu Agency (21 Eylül 2020). https://www.aa.com.tr/en/middle-east/bahrains-king-deal-with-israelhistoric-step-/1980873.

Entous, Adam. “Donald Trump's New World Order”. Newyorker (18 Haziran 2018).

https://www.newyorker.com/magazine/2018/06/18/donald-trumps-new-worldorder.

Farrell, "What's in Trump's Middle East peace plan". Reuters (28 Ocak 2020), https://www.reuters.com/article/uk-israel-palestinians-plan-explaineridUKKBN1ZR1JH 
Fars News Agency. "Riyadh: Palestinians Should Come to Negotiating Table or Shut Up" (30 Nisan 2018). https://www.farsnews.ir/en/news/13970210000327/RiyadhPalesinians-Shld-Cme-Negiaing-Table-r-Sh-Up.

Feuerwerger, Marvin C. Congress and Israel: Foreign Aid Decision-Making in the House of Representatives, 1969-1976. Westport, CT: Greenwood Press, 1979.

Firstpost. "My number one priority is to dismantle the deal with Iran, it is

catastrophic: Trump". (22 Mart 2016), https://www.firstpost.com/world/my-numberone-priority-is-to-dismantle-the-deal-with-iran-it-is-catastrophic-trump2689448.html.

Gerson, Michael. "Trump is evangelicals "dream president". Here's why". The Washington Post (1 Mayıs 2017), https://www.washingtonpost.com/opinions/trump-isevangelicals-dream-president-heres-why/2017/05/15/77b1609a-3996-11e7a058-ddbb23c75d82_story.html.

Grossman, Michael Orlov, Matthews, Ronald Eric. Perspectives on the Legacy of George W. Bush. Newcastleupon- Tyne: Cambridge Scholars Publishing, 2009.

Griswold, Eliza. Franklin Graham's Uneasy Alliance With Donald Trump. The Newyorker (11 Eylül 2020), https://www.newyorker.com/news/dispatch/franklin-grahamsuneasy-alliance-with-donald-trump.

Guez, Jack. "'Stay strong Israel,' Trump tweets as settlement row flares”.

France24 (28 Aralık 2016). https://www.france24.com/en/20161228-israel-trumptweet-settlement-jerusalem-kerry.

Hankins, Barry. American Evangelicals: A Contemporary History of a Mainstream Religious Movement. Lanham: Rowman \& Littlefield, 2008.

Henne, Peter. "US-Israeli Christian leader discusses peace process with Saudi

crown prince". Duckofminerva (13 Eylül 2019). https://duckofminerva.com/2019/09/ifyou-mention-the-evangelical-delegation-to-saudi-arabia-id-have-to-ask-whichone.html.

Herbers, John. "Religious Leaders tell of worry on Armageddon view ascribed to Reagan". The Newyork Times (21 Ekim 1984). https://www.nytimes.com/1984/10/21/us/religious-leaders-tell-of-worry-onarmageddon-view-ascribed-to-reagan.html.

Hirsch, M. "The Legal Status of Jerusalem Following the ICJ Advisory Opinion on the Separation Barrier". Israel Law Review. 38, 298-315, 2005.

Ignatius, David. "Bahrain's diplomatic agreement with Israel is a building block toward Middle East stability". The Washington Post (11 Eylül 2020). https://www.washingtonpost.com/opinions/2020/09/11/bahrains-diplomaticagreement-with-israel-is-building-block-toward-middle-east-stability/.

IMFA, Israel Ministry of Foreign Affairs. PM Netanyahu addresses UN General Assembly (Ekim 2013). http://mfa.gov.il/MFA/PressRoom/2013/Pages/PM-Netanyahuaddresses-UN-General-Assembly-1-Oct-2013.aspx.

Garnham, David. Factors Influencing Congressional Support Israel During the 93rd Congress. The Jerusalem Journal of International Relations. c.2, s.3 (1977), 23-45. 
Isserman Maurice, Kazin, Michael. America Divided: The Civil War of the 1960s. 4.bs. (New York: Oxford University Press, 2011).

Jaffe-Hoffman, Maayan. "How Trump traded annexation for his Christian base". The Jerusalem Post (13 Ağustos 2020). https://www.jpost.com/americanpolitics/how-trump-traded-annexation-for-his-christian-base-analysis-638578.

Jewish Teleghraphic Agency. "Ford Backs off on His Former Proposal That the

U.S. Move Its Embassy in Israel to Jerusalem" (29 Ağustos 1974). https://www.jta.org/1974/08/29/archive/ford-backs-off-on-his-formerproposal-that-the-u-s-move-its-embassy-in-israel-to-jerusalem.

Jewish Telegraphic Agency. "Carter Reserves Decision on Moving U.S. Embassy in Israel to Jerusalem” (2 Eylül 1976). https://www.jta.org/1976/09/02/archive/carterreserves-decision-on-moving-u-s-embassy-in-israel-to-jerusalem.

Jones, Emily. “Trump Says He Moved US Embassy to Jerusalem 'For the Evangelicals'”, The Christian Broadcasting Network (18 Ağustos 2020), https://www1.cbn.com/cbnnews/israel/2020/august/trump-says-he-movednbsp-us-embassy-to-jerusalem-lsquo-for-the-evangelicals-rsquo.

Kershner, Isabel, Halbfinger, David M. “Capital in Trump Mideast Plan Makes 'a Joke' of Palestinian Aspirations". The New York Times (31 Ocak 2020). https://www.nytimes.com/2020/01/31/world/middleeast/trump-mideastplan-jerusalem.html.

Landau, Noa. "FULL TEXT: The Israel-UAE-Bahrain Abraham Accords Peace Agreement", Haaretz (16 Eylül 2020). https://www.haaretz.com/middle-east-news/.premiumfull-text-the-israel-uae-bahrain-abraham-accords-declaration-1.9159509.

Lahr, Angela M. Millennial dreams and apocalyptic nightmares: the Cold War origins of political evangelicalism. Oxford: Oxford University Press, 2007.

Leonard, Robert. Visions of Apocalypse. Maryland: John Hopkins University Applied Physics Labaratory, 2010.

Lewis, Jeffrey. "That Secret Iranian 'Nuclear Facility' You Just Found? Not So Much". Foreign Policy (3 Mart 2015). https://foreignpolicy.com/2015/03/03/thatsecret-iranian-nuclear-facility-you-just-found-not-so-much/.

Lipka, Michael. "More White Evangelicals than American Jews say God gave Israel to the Jewish People". Pew Research Center (3 Ekim 2013). https://www.pewresearch.org/fact-tank/2013/10/03/more-white-evangelicalsthan-american-jews-say-god-gave-israel-to-the-jewish-people/.

Marsden, George M. Fundamentalism and American Culture: The Shaping of TwentiethCentury Evangelicalism. Oxford: Oxford University Press, 2006.

Martinez, Jessica - Smith, Gregory A. "How the faithful voted: A preliminary 2016 analysis, Pew Research Center (9 Kasım 2016). https://www.pewresearch.org/facttank/2016/11/09/how-the-faithful-voted-a-preliminary-2016-analysis/.

Middle East Eye. "Israel and UAE held secret anti-Iran meeting at White House: Report" (4 Şubat 2020). https://www.middleeasteye.net/news/israel-uae-secret-antiiran-white-house. 
Mitchell, Chris. "Freedom Is Unfolding in This Arab Country: US Evangelicals Find UAE 'Treasure of Moderation'". CBN News (31 Ekim 2018), https://www1.cbn.com/cbnnews/world/2018/october/freedom-is-unfoldingin-this-arab-country-us-evangelicals-find-uae-treasure-of-moderation.

Mitchell, Chris. "Evangelical Leaders See the Untold Story of Saudi Arabia in 'Historic' Trip". CBN (13 News Eylül https://www1.cbn.com/cbnnews/israel/2019/september/evangelical-leaderssee-the-untold-story-of-saudi-arabia-in-historic-trip.

Noll, Mark A. "The American Revolution and Protestant Evangelicalism". The Journal of Interdisciplinary History, 23(3), 617-627, 1993.

Oldmixon, E. A., Rosenson, B. A., Wald, K. D. Conflict Over Israel: The Role of Religion, Race, Party and Ideology in the U.S. House of Representatives, 1997-2002. Terrorism and Political Violence, 17 (3), 407-426, 2005.

Paker, Peter. "An Embassy in Jerusalem? Trump Promises, but So Did Predecessors". The New York (19 Times Kasim 2016). https://www.nytimes.com/2016/11/19/world/middleeast/jerusalem-usembassy-trump.html.

PASIA, Palestinian Academic Society for the Study of International Affairs. Documents on Jerusalem. Jerusalem: PASSIA Publication, 2007. http://passia.org/media/filer_public/e7/d1/e7d1d05e-6c27-43f3-9ea4384ad43c7746/vol-1-documents-on-jerusalem.pdf.

Pfeffer, Anshel. "Mossad Chief Reportedly Visited Saudi Arabia for Talks on Iran”. Haaretz (26 Temmuz 2010), https://www.haaretz.com/1.5152341.

Preston, Andrew. Sword of the Spirit, Shield of Faith: Religion in American War and Diplomacy (London: Amazon Media, 2012).

Reuters. "Kosovo follows U.S., Guatemala in opening embassy in Jerusalem". (14 Mart 2021), https://www.reuters.com/article/us-israel-kosovo-embassy/kosovofollows-u-s-guatemala-in-opening-embassy-in-jerusalem-idUSKBN2B60FG?il=0.

Rosenberg, Joel C. “Secretary Pompeo's Iran speech: Tehran hated it. But most Arab \& Israeli leaders loved it. So did I. Here's why" (23 Mayis 2018). https://flashtrafficblog.epicentermedia.net/2018/05/.

Rosenberg, Joel C.. "Pompeo in Iowa makes case to Evangelical conference that Trump team is the most pro-Israel administration in US history. But makes no mention of annexation" (20 Temmuz 2020). https://flashtrafficblog.epicentermedia.net/2020/07/20/exclusive-pompeo-iniowa-makes-case-to-evangelical-conference-that-trump-team-is-the-most-proisrael-administration-in-us-history-but-makes-no-mention-of-annexation-isannexation-off-us-agenda-for/.

Rosenberg, Joel C. "Israel and UAE agree to full normalisation of relations" (13 Ağustos 2020). https://flashtrafficblog.epicentermedia.net/2020/08/13/breaking-israeland-uae-agree-to-full-normalization-of-relations/.

Rosenberg, Joel C. "Iran's terror regime the "most terrible institution in the world," US Secretary of State Pompeo tells" (29 Eylül 2020). https://allarab.news/irans- 
terror-regime-the-most-terrible-institution-in-the-world-us-secretary-of-statepompeo-tells-all-arab-news/.

Sandeen, Ernest R. "The Roots of Fundamentalism: British and American Millenarianism". Illionis: University of Chicago Press, 2008.

Sanger, David E. - Kirkpatrick, David D. “Behind Trump's Termination of Iran deal is a Risky Bet". The New York Times (8 Mayls 2018), https://www.nytimes.com/2018/05/08/us/politics/trump-iran-nuclear-dealnews-analysis-.html.

Spector, Stephen. This Year in Jerusalem: Prophecy, Politics, and the U.S. Embassy in Israel. Journal of Church and State, 1-21, 2019.

Spiegel, Steven L. The Other Arab-Israeli Conflict: Making American Middle East Policy, from Truman to Reagan. Chicago: University of Chicago Press, 1985.

Stewart, Katherine. "Why Trump Reigns as King Cyrus", The New York Times (31 Aralık 2018), https://www.nytimes.com/2018/12/31/opinion/trump-evangelicalscyrus-king.html, 31.07.2020.

Pompeo, Michael R. Being a Christian Leader (11 Ekim 2019). https://www.state.gov/being-a-christian-leader/.

The Economist. "The politicisation of white evangelical Christianity is hurting it". 28 Şubat 2019, https://www.economist.com/united-states/2019/02/28/thepoliticisation-of-white-evangelical-christianity-is-hurting-it.

Trump, Donald. "Remarks at a Cabinet Meeting and an Exchange With Reporters".

9 Mayıs 2018, https://www.presidency.ucsb.edu/documents/remarks-cabinet-meetingand-exchange-with-reporters-4.

Trump, Donald. "State of the Union 2019: Read the full transcript". CNN (6 Şubat

2019), https://edition.cnn.com/2019/02/05/politics/donald-trump-state-of-the-union2019-transcript/index.html.

Wilner, Michael. "Trump supports $\$ 75 \mathrm{~m}$. additional aid to Israel beyond Obama-era MOU”. The Jerusalem Post (11 Eylül 2017). https://www.jpost.com/israelnews/trump-supports-75m-supplemental-aid-to-israel-beyond-obamaera-mou504800.

Wintour, Patrick - Holmes, Oliver. "Mike Pence Chides US Allies at Warsaw Summit on Iran". The Guardian (14 Şubat 2019). https://www.theguardian.com/world/2019/feb/14/us-and-israel-sayconfrontation-with-iran-needed-for-peace. 